\title{
BIODEGRADATION OF \\ TRISODIUM NITRILOTRIACETATE \\ IN A MODEL AERATED \\ SEWAGE LAGOON
}

\begin{abstract}
A Thesis
Submitted to

the Faculty of Graduate Studies and Research

University of Manitoba
\end{abstract}

In Partial Fulfillment

of the Requirements for the Degree

Master of Science

by

John William McCullagh Rudd

August, 1971

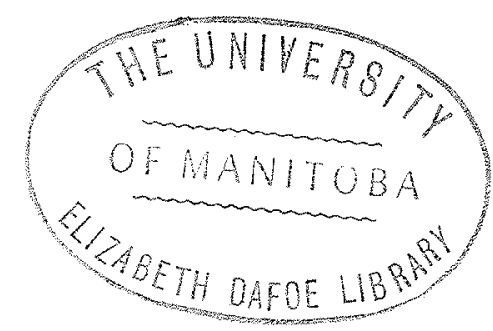




\section{ACKNOWLEDGEMENTS}

The writer grants his appreciation to Dr。 R.D. Hamilton, Adjunct Professor of the Department of Microbiology, University of Manitoba, for his advice during the course of this investigation and assistance in the preparation of this manuscript. Appreciation is also granted to Dr. H. Lees, Head of the Department of Microbiology, for his assistance throughout this project.

Gratitude is extended to Dr. D. Poveledo, Mr。D. Murray, and Mr。 M. Pitze of the Fisheries Research Board of Canada, Freshwater Institute, for their kind advice and patient assistance with gas chromatographic methods. Appreciation is granted to Dr. K. Patalas, also of the Freshwater Institute, for his assistance in the identification of zooplankton samples.

Gratitude is granted to Mr。W. Carrol of the Metropolitan Corporation of Greater Winnipeg, Water Works and Waste Disposal Division, for his continued co-operation and interest during this study and particularly for assistance in obtaining raw sewage samples. Appreciation is granted to the Metropolitan Corporation of Greater Winnipeg for unlimited access to the Charleswood Lagoon. 
iii

TO LESLEY 


\section{ABSTRACT}

A model lagoon was designed to imitate an aerated portion of the Charleswood Sewage Lagoon. Results of standard sewage treatment tests indicated that it was possible to operate such a model in a manner which closely approximated the actual lagoon. Biodegradation of expected concentrations of NTA was followed at $15^{\circ} \mathrm{C}, 5^{\circ} \mathrm{C}$ and $0.5^{\circ} \mathrm{C}$. At these temperatures NTA removal efficiencies were $93 \%, 47 \%$ and $25 \%$ respectively. Aerated lagoons located in the prairie provinces may be expected to discharge approximately $10 \mathrm{mg}$ NTA/L during winter months. Presence of a bacterial predator, Daphnia, in the system was believed to enhance the biodegradation of NTA. 
INTRODUCTION HISTORICAL

Description of the Charleswood Air-Aqua
System ........

Description of the Model Lagoon ....... 16

Model Lagoon Specifications ...... 16

Aeration ............ 17

Temperature Control ........ 18

The Raw Sewage Samples ......... 19

Lagoon Startup ........... 19

Analysis of Model Lagoon Performance ...... 20

Dye Test ............ 20

$\mathrm{pH}$. . . . . . . . . . . . 21

Dissolved Oxygen ........... 21

Biological Oxygen Demand (BOD) ..... 23

Total Suspended Solids ......... 23

Chemical Oxygen Demand (COD) ...... 24

Nitrate and Nitrite ......... 25

Ammonia ............ 28

Total Phosphate ........... 28

NTA Analysis ............ 29

RESULTS AND DISCUSSION

Retention Times .............. 31 
TABLE OF CONTENTS CONT'D

PAGE

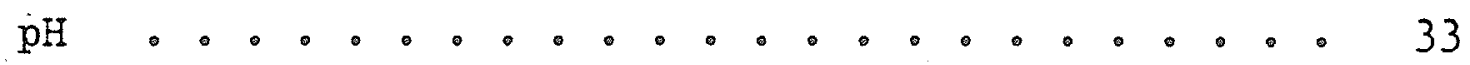

Total Phosphate ............. 34

Inorganic Nitrogen . . . . . . . . . . 35

Biological Oxygen Demand (BOD) ….... 37

Chemical Oxygen Demand (COD) ........ 38

Dissolved Oxygen ............. 40

Suspended solids . . . . . . . . . . 41

Algal and Daphnia Blooms .......... 42

Biodegradation of INTA

Efficiency of Lagoon Sewage Treatment

GENERAL CONCLUSIONS

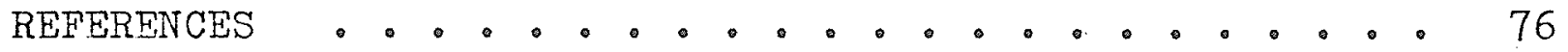


LIST OF TABLE, PLATE AND FIGURES

TABLE

PAGE

I. Comparison of the operational characteristics of the model lagoon and the Charleswood

Air-Aqua system $. . \circ . . . . . . . . . . . .$.

PLATE

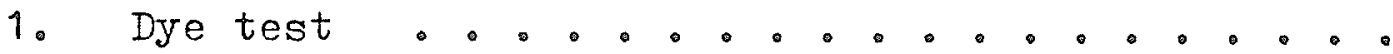

FIGURE

1. $\mathrm{pH}$ of the primary and secondary cells of the

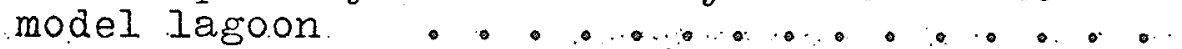

2. Total phosphate concentration in the secondary effluent of the model lagoon ........

3. Nitrate-N and nitrite-N concentration in the secondary effluent of the model lagoon..

4. BOD of the secondary effluent of the model lagoon

5. COD of the secondary effluent of the model

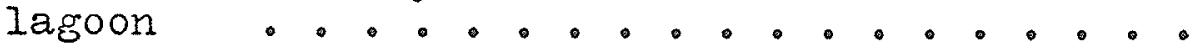

6. Dissolved oxygen concentration in the primary and secondary cells of the model lagoon .....

7. Suspended solids concentration in the secondary effluent of the model lagoon.......

8. Acid NTA concentration in the secondary effluent of the model lagoon .............

9. Rate of ITA breakdown, by the model lagoon, as a function of temperature ..........

10. The effect of Daphnia on the percentage breakdown of NTA 
INTRODUCTION 


\section{INTRODUCTION}

In the near future, sodium nitrilotriacetate $\left(\mathrm{Na}_{3} \mathrm{NTA}\right)$ may partially or completely replace sodium tripolyphosphate as a builder in synthetic detergents. If this replacement occurs, the consumption of $\mathrm{Na}_{3} \mathrm{NTA}$ may reach one to two billion pounds per year in North, America (1)。 It is therefore imperative that we learn more about the biodegradation of this synthetic product in the environment.

Sewage lagoons are frequently used as a means of conditioning industrial and domestic wastes $(2,3,4)$. Consequently, they will receive a large portion of the $\mathrm{Na}_{3} \mathrm{NTA}$ production in their influent. These lagoons are used widely for waste disposal in small towns and cities in the Canadian prairie provinces where sufficient land is available at a reasonable cost. One hundred and ninety-eight communities in the prairie provinces are presently serviced by this type of sewage treatment system (5). As the communities serviced by unaerated lagoons expand, the load on their sewage treatment systems will increase. The most economical means to increase the capability of an unaerated lagoon is to install an aeration system. Twelve of the above communities have installed aeration systems in their lagoons. Lagoons situated on the prairie provinces operate at very low temperatures during the winter months (6). This cannot help but reduce their efficiency and ability to deal with a novel compound such as NTA. It was therefore deemed advisable to initiate 
a study on the biodegradation of $\mathrm{Na}_{3} \mathrm{NTA}$ in aerated sewage lagoons operated at temperatures which commonly occur in the prairie provinces. It was believed that a practical means of accomplishing this would be to construct a model aerated sewage lagoon which would duplicate as closely as possible conditions prevailing in an actual sewage lagoon. The design, construction and testing of this model was a major portion of this project. The model lagoon is a scaled down version of an aerated portion of the Charleswood Sewage Lagoon, which services a mainly residential portion of Metropolitan Winnipeg。 
HISTORICAL 


\section{HISTORICAI}

The rapid eutrophication of many bodies of water have been related to the increase in phosphorus loading due to the increase in human population and their activities $(7,8)$.

One of the major contributors to the phosphate in sewage has been found to be the tripolyphosphate originating from detergents. Detergent phosphate has been estimated to contribute $35 \%$ - $49 \%$ and $28.5 \%$ - $40 \%$ of the total phosphate input into Lakes Erie and Ontario respectively (9). The International Joint Commission has concluded that the removal of phosphates from detergents would be one of the means of alleviating the eutrophication of these lakes (10). Although input levels have not been precisely documented for many other lakes, it is reasonable to suppose that in most cases detergents have been one of the major contributors of phosphates. Because of this, efforts have been made to find a replacement for tripolyphosphate as a detergent builder.

The functions of a detergent builder have been found to be: chelating cations (principlely $\mathrm{Ca}^{+}$and $\mathrm{Mg}^{+}$) thus softening the wash water and enabling the detergent to clean more effectively, lowering the critical micelle concentration, and helping to buffer the wash water (11).

Since 1967, $\mathrm{Na}_{3} \mathrm{NTA}$ has been used successfully as a detergent builder in sweden. It has been found to be less likely to contribute to increased eutrophication since, if $100 \%$ of the phosphate in detergent was replaced by $\mathrm{Na}_{3} \mathrm{NTA}^{\mathrm{N}}$ 
the increase of nitrogen and carbon in $r$ aw sewage would only be $1.35 \mathrm{mg},-\mathrm{N} / 1$, and $7.0 \mathrm{mg},-\mathrm{N} / 1$ 。 respectively or approximately $4 \%$ (12). This increment would be comparable to the reduction of phosphate in raw sewage by approximately $66 \%$ (13).

NTA was first discovered in 1862 by Heintz, while attempting to synthesize glycine from ammonia and monochloracetic acid (14). At this time no technical applications were suspected. It was not until 1935 that Munz, working in the I. G. Farbenindustrie A. Go. Laboratories, discovered that NTA, in the crude reaction product of ammonia and monochloracetic acid, prevented the precipitation of insoluble salts and soaps of calcium and magnesium (15). In 1945, the first systematic analysis of EDTA and NTA was begun by Schwarzenbach (15). These studies contributed much to the present day chemical knowledge of NTA. About 1950, work was begun on the development of industrial production of the amino carboxylic acids (15). However, NTA has had restricted application until recently because of high production costs. For example, it has been used commercially as a water softener (16). It has also been used as a chelating agent in artificial algal media (17). In 1962, a process was patented in the United States which made the production of large quantities of $\mathrm{Na}_{3} \mathrm{NTA}$ possible, at a price competitive with tripolyphosphate (16). By 1969, Hampshire Chemical Company and Monsanto Chemical Company, producers of most of the 
$\mathrm{Na}_{3} \mathrm{NTA}$ in the United States, were synthesizing it at a rate of 150 million pounds per year (9). Proctor and Gamble announced that by May, 1970 they intended to replace 25\% of the phosphates with $\mathrm{Na}_{3} \mathrm{NTA}$ in one-third of their brand name detergents. They also announced that they intended to reach $50 \%$ replacement shortly thereafter (12). It has been estimated that the consumption of $\mathrm{Na}_{3} \mathrm{NTA}$ may reach one to two billion pounds per year in North America (1)。

Research has been carried out into the toxicology of

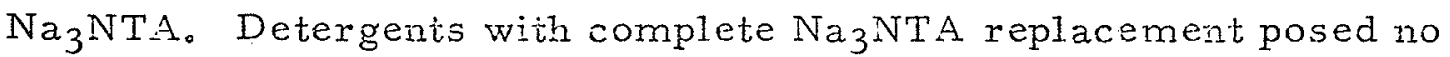
safety problem during tests of eye irritation, cutaneous allergic response, and sub-acute percutaneous toxicity (18).

Levels of one hundred times the estimated maximum human intake $\left(0.13 \mathrm{mg} / \mathrm{Kg} \cdot /\right.$ day at $50 \% \mathrm{Na}_{3} \mathrm{NTA}$ replacement) during chronic rat feeding studies resulted in no toxic effects (19). However, in excess of. $03 \% \mathrm{Na}_{3} \mathrm{NTA}$ as feed there was increased incidence of chronic nephritis (19).

Trisodium NTA was found to be slightly more toxic than tripolyphosphate in rat acute oral toxicity tests (19).

During sub-acute feeding studies, when rat feed contained $0.75 \% \mathrm{Na}_{3} \mathrm{NTA}$, there was increased concentration of urinary zinc. At $2 \% \mathrm{Na}_{3} \mathrm{NTA}$ in feed there was significant increases in urinary $\mathrm{pH}$ as well as in concentrations of zinc, calcium, and sodium (19). Metabolic studies using ${ }^{14} \mathrm{C}$ labelled NTA indicated that only $3 \%$ of ingested NTA remained in the rat body after 72 hours. 
The balance was excreted unchanged in the urine (20). Most of the unexcreted NTA carbon was found in the skeleton. It was concluded that incorporation of NTA into bone would have no significant effect on bone development since the amount of NTA incorporated represented only $0.007 \%$ of the total calcium turnover in 24 hours (20).

There was no evidence of adverse reproductive or embryogenic effects when $\mathrm{Na}_{3} \mathrm{NTA}$ was added to rat diets at a level of $0.1 \%$. However, at $0.5 \%$ there was a slight fetal toxic effect (19). Also, $\mathrm{Na}_{3} \mathrm{NTA}$ was not carcinogenic for rats (19). The effects of $\mathrm{Na}_{3} \mathrm{NTA}$ on aquatic animals have also been studied. It has been found that trout can live in water containing up to $400 \mathrm{mg}$./ $\mathrm{Na}_{3} \mathrm{NTA} / 1$, with no apparent adverse effects. However, these concentrations were lethal if $\mathrm{pH}$ was not controlled (21). Trisodium NTA was found to be nontoxic to fathead minnows at concentrations of up to $100 \mathrm{mg} \cdot / \mathrm{Na}_{3} \mathrm{NTA} / 1$.(11). The presence of $\mathrm{Na}_{3} \mathrm{NTA}$ enabled fish to live in water containing otherwise lethal concentrations of copper and zinc (22)。 Studies have been carried out on tubificid worms as well as various crustacea and fishes. It has been concluded that $\mathrm{Na}_{3} \mathrm{NTA}$ in concentrations above $200 \mathrm{mg}$ / 1 。 were toxic。 Trisodium NTA in sea water was invariably more toxic than in fresh water. This toxicity was thought to be the result of $\mathrm{Na}_{3} \mathrm{NTA}$ lowering the $\mathrm{pH}$ (23). Another study indicated that during 96 hour median tolerance limit tests concentrations of up to 500 mg./1. buffered $\mathrm{Na}_{3} \mathrm{NTA}$ had no direct toxic effect on 17 species 
of macroinvertebrates and 2 species of amphibians. However, the rise in $\mathrm{pH}$ especially in soft waters as a result of addition of $\mathrm{Na}_{3} \mathrm{NTA}$ was sufficiently large to be lethal to $\mathrm{pH}$ sensitive aquatic animals (1). The concentrations of $\mathrm{Na}_{3} \mathrm{NTA}$ found to be toxic to aquatic animals were far in excess of these expected to occur in practice. It has been estimated that $100 \%$ replacement of the phosphate in detergents by $\mathrm{Na}_{3} \mathrm{NTA}$ would result in NTA concentrations in receiving waters of approximately $2 \mathrm{mg} / \mathrm{NTA} / \mathrm{I}_{\text {。 }}$ assuming no biodegradation (24).

Research has also been carried out into the effect of NTA on algae. It has been found that the compound was nontoxic to lạboratory cultures of Chlorella pyrenoidosa at concentrations of up to $275 \mathrm{mg} \cdot / \mathrm{Na}_{3} \mathrm{NTA} / 1 .(25)$. Trisodium NTA could act as a nitrogen source for some algal cultures (25, 26, 27). However, when Chlorella was cultured in sludge supernatant plus up to 27.5 mg./Na3 NTA/1. no significant difference could be found between these cultures and sludge supernatant controls. This was thought to have resulted from a masking effect by the sludgesupernatant (25). The addition of $10 \mathrm{mg} / \mathrm{Na}_{3} \mathrm{NTA} / 1$. increased algal growth in sewage treatment effluent chemically treated for phosphate removal while addition of $1 \mathrm{mg} / / \mathrm{Na}_{3} \mathrm{NTA} / 1_{\text {. and }} 5 \mathrm{mg} \cdot / \mathrm{Na}_{3} \mathrm{NTA} / \mathrm{I}_{\text {。 only }}$ slightly increased algal growth (27).

NTA is a chelating agent and such compounds can improve the transfer of trace metals from the growth medium to the algal cells。 The presence of 1 or $5 \mathrm{mg} \cdot / \mathrm{Na}_{3} \mathrm{NTA} / 1$ 。 stimulated ${ }^{14} \mathrm{C}$ assimilation by $15 \%$, in iron-limited phytoplankton cultures 
growing in water from hard water lakes (28). Other studies suggested that the presence or absence of NTA in phosphatestripped sewage effluent had practically no effect on iron and trace elements necessary for algal growth (27). The specific effects of NTA chelation in the environment have been clouded by the presence of various natural chelators which may or may not be sufficient to mask the presence of NTA at expected maximum concentrations ( $2 \mathrm{mg}$ - $\left.-\mathrm{NTA} / \mathrm{l}_{0}\right)$.

Since the toxic or stimulatory effects of NTA are dependent upon its concentration the removal of this compound from the environment by biodegradation is of paramount importance.

Bacterial populations present in lab scale and field sewage treatment systems have been found to be unable to use $\mathrm{Na}_{3} \mathrm{NTA}$ constituitively. Several studies have indicated that periods of from several days to several weeks were required for acclimation $(29,30,31,32,33)$. The duration of the acclimation period appeared to be dependent upon several factors some of which were: $\mathrm{Na}_{3} \mathrm{NTA}$ concentration, sludge concentration, and temperature. Two day interruptions of the delivery of $\mathrm{Na}_{3} \mathrm{NTA}$ to activated sludge systems resulted in no change in biodegradation efficiency when $\mathrm{Na}_{3} \mathrm{NTA}$ was reintroduced $(24,32)$. However, there was loss of acclimation if $\mathrm{Na}_{3} \mathrm{NTA}$ was withheld from these systems for 3 or 5 days $(24,32)$ although the reacclimation period was shorter than when the $\mathrm{Na}_{3} \mathrm{NTA}$ was first introduced. It was also discovered that laboratory activated sludge systems containing high 
concentrations of sludge were not as prone to loss of acclimation during intermuption of $\mathrm{Na}_{3} \mathrm{NTA}$ as were those with low sludge concentrations (24).

Following acclimation, laboratory semi-continuous and continuous activated sludge plants, operating with synthetic sewage and at room temperature, removed $\mathrm{Na}_{3} \mathrm{NTA}$ with efficiencies of greater than $90 \%$ under ideal operating conditions $(31,34)$.

-Trisodium NTA did not have any apparent effect on the normal operation of either lab scale or field activated sludge treatment systems $(31,33,34)$.

Shumate et al (33) have demonstrated $90 \% \mathrm{Na}_{3} \mathrm{NTA}$ breakdown in a municipal activated sludge plant fed $8.0 \mathrm{mg} .-\mathrm{NTA} / \mathrm{l}$. Breakdown efficiency was concentration dependent since only $75 \%$ biodegradation was observed at a NTA influent concentration of $16.0 \mathrm{mg} \cdot-\mathrm{NTA} / \mathrm{I}$.

Bouveng et al (35) have monitored NTA breakdown in a trickling filter whose effluent flows through both a secondary clarifier and an oxidation pond. It was found that, during summer and fall under normal operating conditions, approximately $90 \%$ of the incoming NTA was degraded in the trickling filter. The remainder was broken down in the oxidation pond. Increases in hydraulic load were found to adversely affect NTA breakdown.

Biodegradation of NTA under anaerobic conditions was found to be questionable. Swisher and Hitchell (24) reported that Bouveng suggested that there is rapid degradation anaerobically. However, other investigators have been unable 
to demonstrate this (12). Three anaerobic systems might be expected to be major sources of undegraded NTA: anaerobic digesters, cesspools, and septic tanks. In the case of septic tanks however, NTA should be degraded under the aerobic conditions present in the associated tile field.

Research has also been carried out on the fate of NTA entering waterways either in effluent from sewage treatment systems or in raw sewage from areas having no sewage treatment. It has been estimated that greater than $95 \%$ of NTA present in activated sludge effluent will be degraded two miles downstream from the plant (33). In another study, river water samples taken downstream from a sewage treatment plant were capable of degrading NTA after 8-12 days of acclimation. It was estimated that up to $5 \mathrm{mg} \cdot-\mathrm{NTA} / \mathrm{I}$. could be degraded in this stream within one day (34). Small numbers of bacteria capable of degrading NTA have been isolated from Scandinavian waterways. The bacteria occurred most often in water polluted by sewage (29).

Metal ions form stable complexes with NTA. Biodegradation of metal ion complexes may be inhibited if the complex has a high stability constant. However, NTA plus equimolar amounts of $\mathrm{Fe}^{\mathrm{t+t}}$ were degraded as well as NTA alone at $\mathrm{pH} 7-8$ (31). This experiment gave no information as to whether the iron complex itself was degraded directly, or whether dissociated NTA was attacked (31). Also, growth of bacteria on calcium complexed NTA was similar to that of $\mathrm{Na}_{3} \mathrm{NTA}$ (29). Calcium 
chelates of NTA are one of the major NTA complexes present in wash water (12). Other metal complexes may not be degraded so readily ( 36$)$.

Carbon dioxide production during NTA degradation suggested that the first step of NTA breakdown was carried out by the cleaving of two acetate groups from the NTA molecule. The remaining molecule of glycine could then be metabolized through known biochemical pathways (34). 
MATERIALS AND METHODS 


\section{MATERIALS AND METHODS}

\section{DESCRIPTION OF THE CHARLESWOOD AIR-AQUA SYSTEM}

The Charleswood Air-Aqua system is composed of primary and secondary cells. The primary cell is 390 feet long, 250 feet wide and 10 feet deep. The secondary cell is 380 feet long, 250 feet wide, and 10 feet deep. Raw sewage enters the lagoon through two delivery mains near the influent end of the primary cell. A single overflow pipe connects the primary and secondary cells. A notched control weir regulates the effluent from the secondary cell.

The total volume of the lagoon is $15 \times 10^{6}$ gallons. Thus, at a raw sewage influent rate of 0.5 imperial million gallons per day, the lagoon has a theoretical retention time of 30 days. The retention time is constant year round.

The process loading is $0.521 \mathrm{bs} . \mathrm{BOD}_{5} / 1000 \mathrm{ft}^{3} /$ day. Lagoon efficiency was designed to be $90 \%$.

The aeration system operates on the diffused air principle. Air bubbles are released from the upper face of plastic aeration tubes laid across the bottom of the cells. The tubing is spaced to provide tapered aeration. That is, there is maximum aeration near the influent end of the primary where BOD is the highest. Spacing of the aeration tubes varies from 2.5 to 20 feet. The aeration system is designed so that the lagoon will operate at a dissolved oxygen concentration of $2.0 \mathrm{mg} \cdot / 1$.

The Air-Aqua system is described as being an "aerobic- 
anaerobic" system. That is, the aeration is designed to sustain a dissolved oxygen concentration of $2.0 \mathrm{mg} / \mathrm{l}_{0}$ in the water column. However, agitation by the air bubbles is not sufficient to keep all solids in suspension. A portion of the biodegradable and non-biodegradable solids in the influent plus some of the microorganisms settle out as sludge. Anaerobic breakdown is then carried out in the sludge. This system has the advantage of having a low concentration of suspended solids in the secondary effluent. Thus settling of the suspended solids in the secondary effluent is not required before the effluent is discharged into receiving waters.

DESCRIPTION OF THE MODEL LAGOON

Model Lagoon Specifications

The lab scale sewage lagoon was designed to approximate conditions prevailing in the Charleswood Air-Aqua system as closely as possible (37). Since scaling down of the actual lagoon cells would have resulted in a prohibitively shallow depth it was decided that the operating depth of the model lagoon should be one foot and that the width to length ratio $(0.66)$ of the model lagoon cells should be the same as the Air-Aqua cells. Each cell therefore had interior dimensions of $45.5^{\prime \prime} \times 30^{\prime \prime} \times 18^{\prime \prime}$. At the operating depth of one foot each cell contained 71.06 gallons. 
The primary and secondary cells were constructed with 3/8" plate glass. The glass was glued together with Silicone Seal (General Electric Company) which provided adequate support as well as a water tight seal. Both cells were constructed with double walls and the $1 / 2^{\prime \prime}$ space between the walls was filled with Zonalite insulation. One-eighth inch $I, D$, tygon tubing was used in the overflow systems between the primary and secondary cells and for the final effluent from the secondary cell.

Aeration

The aeration system was composed of an external 1/8" I. D. tygon line running along the front of the tanks (plate 1). Fifteen needle valves were spliced into this line and controlled the air flow to fifteen 1/32" I. D. tygon tubes which had single openings in the centre of the tanks. Movement of the aeration tubes along the bottom of the tanks was prevented by inserting them into $3 / 16^{\prime \prime} I_{0} D$. glass tubing before they were placed on the bottom of the tanks. The aeration tubes were spaced to provide tapered aeration with maximum air supply at the influent end of the primary where BOD content of the water was highest. Spacing between the tubes from the influent end of the primary to the effluent end of the secondary varied from 4" to 8". Tapering of the aeration system required nine air outlets in the primary and six in the secondary.

The line pressure was regulated at $0.51 \mathrm{bs} . / \mathrm{in}_{0}{ }^{2}$ for the runs at 
$5^{\circ} \mathrm{C}$ and $0.5^{\circ} \mathrm{C}$. Because of high oxygen demand as a result of raising the lagoon temperature to $15^{\circ} \mathrm{C}$ the air pressure was raised to $11 \mathrm{~b}$ / $/ \mathrm{in}^{2}$ during this period. Oxygen concentration was monitored periodically, to ensure that the oxygen tension never fell below $2 \mathrm{mg} / 1$. This level is the highest estimate of the limit of aerobic breakdown in sewage treatment systems (38).

\section{Temperature Control}

The water temperature of the lagoon was controlled by pumping a coolant through $1 / 4$ " I. D。 glass cooling coils. The coils were glued around the inside surface of the tanks at levels of $1^{\prime \prime}, 4^{\prime \prime}, 7^{\prime \prime}$, and $10^{\prime \prime}$ below the water level. For the runs at $5^{\circ} \mathrm{C}$ and $15^{\circ} \mathrm{C}$ the coolant coils in both tanks were linked in series and a single pump circulated the coolant through the coils at a rate of $1080 \mathrm{ml} / \mathrm{min}$.

However, when the tanks were controlled at $0.5^{\circ} \mathrm{C}$ antifreeze was required in the cooling bath. Therefore because of the high viscosity of the coolant and the low temperature desired it was necessary to use a single pump for each tank. Thus at $0.5^{\circ} \mathrm{C}$ the coolant was circulated at a rate of $1200 \mathrm{ml}$. min。 through the primary and $1000 \mathrm{ml} / \mathrm{min}$. through the secondary cell.

To obtain the desired temperature during the run at $0.5^{\circ} \mathrm{C}$ it was necessary to cool the lagoon room to $13^{\circ} \mathrm{C}$ and cover the primary tank with polyethylene.

Coolant was pumped from the temperature controlled water bath of 
Precision Warburg throughout the experiment.

The Raw Sewage Samples

Raw sewage samples were obtained at the control weir in the main control chamber of the Charleswood Sewage Lagoon. Sufficient raw sewage for a two week period was stored, frozen, in 20 1iter quantities. Each sample required 3 hours thawing time in warm tap water. After thawing $10.0 \mathrm{ml}$. of a stock solution of $40.0 \mathrm{~g} \cdot-\mathrm{Na}_{3} \mathrm{NTA} / \mathrm{l}_{\circ}$ (Hampshire Chemical Company, Nashua, New Hampshire) were added to the samples.

This resulted in an effective free acid NTA concentration of 14. $6 \mathrm{mg} \cdot-\mathrm{NTA} / 1$. which is the expected influent concentration of NTA if there is $100 \%$ replacement of detergent phosphates by NTA (24).

During the time the raw sewage samples were being pumped into the lagoon they were cooled to $8^{\circ} \mathrm{C}$ by placing the sewage containers in an insulated water bath.

Raw sewage was pumped at a rate of $12.4 \mathrm{ml} / \mathrm{min}$. into the bottom of the influent end of the primary cell. This pumping rate resulted in a 30 day retention time which is the same retention time as the Charleswood Air-Aqua system. It was pumped through 1/16" I. D。 silicone tubing using a peristaltic pump controlled by a Masterflex SCR

*Precision Scientific Company, Chicago, Illinois, U.S.A. 
controller*

Lagoon Startup

To minimize the time required for the establishment of typical lagoon conditions 71 gallons of both primary and secondary sewage were obtained from the Air-Aqua system of the Charleswood Sewage Lagoon. The two samples were pumped from a point one-half way down the side of each cell. The opening of the pump intake hose was approximately one foot below the water surface. This sewage was used to fill the respective cells of the model lagoon.

The performance of the model lagoon was monitored until conditions stabilized. Subsequently, the raw sewage samples used as feed were replaced by raw sewage containing added NTA.

\section{ANALYSIS OF MODEL LAGOON PEREORMANCE}

The following tests were performed on the model lagoon to ensure that it was, in fact, operating in a manner which closely approximated the Charleswood Air-Aqua system (37)。

\section{Dye Test}

In order to establish the effective retention time of the model lagoon, $2 \mathrm{~g} \cdot / 1$. nigrosin dye was pumped into the influent end of the primary cell at a rate of $12.4 \mathrm{ml} . / \mathrm{min}$. The progress of the dye through the primary *Cole-Parmer Company, Chicago, Hlinois, U.S.A. 
and secondary cells was followed visually and by photography (plate 1)。 Samples were also taken at regular intervals from the secondary effluent. The appearance of nigrosin in the secondary effluent was monitored by a Klett-Summerson photoelectric colorimeter* equipped with a $4 \mathrm{~cm}$. cell and a green filter (500-570 $\mathrm{nm})$ 。

The time taken from introduction of the dye into the raw sewage influent until its appearance in the secondary effluent, as measured by the Klett, was taken to be the effective retention time of the model lagoon.

$\underline{\mathrm{pH}}$

Samples from the primary cell of the model lagoon were obtained near the effluent outlet of the cell from a point $10 \mathrm{~cm}$. below the water surface. The secondary samples were collected from the overflow of the secondary cell. The $\mathrm{pH}$ was measured on a Beckman Zeromatic $\mathrm{pH}$ meter $*$.

Dissolved Oxygen

Dissolved oxygen concentration was measured, as percent saturation, by a Dissolved Oxygen Meter Model 15A***. The measurements were converted to $\mathrm{mg} \cdot \mathrm{O}_{2} / 1$. The primary and secondary cell measurements were taken $2 / 3$ of the way down the cell and midway between the front wall of the tank and surfacing aeration bubbles. The oxygen electrode was submerged $15 \mathrm{~cm}$. below the water surface. This method of dissolved oxygen measurement was used during the period of day 1 to day 115.

\footnotetext{
*Klett Manufacturing Company Incorporated, N.Y。, U.S.A. * Beckman Instruments Incorporated, Fullerton, California, U.S.A. * Electronic Instruments Limited, Richmond, Surrey, England.
} 
After day 115 a modification of the azide modification of the iodometric method (39) was employed because of technical difficulties with the Dissolved Oxygen Meter. Oxygen samples were obtained from the same positions. In this case the samples were obtained by siphon. To obtain accurate samples, the siphon was allowed to mun into a bucket for 30 seconds. Then $300 \mathrm{ml}$. BOD bottles were filled by placing the opening of the siphon tube at the bottom of the bottles. Siphoning was timed and continued until the bottles had been filled 3 times. The tube was then gently removed and the glass stopper was dropped into the neck of the bottle. The BOD bottles were filled 3 times in order to expel any water which had taken up atmospheric oxygen during the first fijling of the bottles. One polyethylene pillow each of mranganous sulfate and alkaline iodide-azide (Hach Chemical Company, Ames, Iowa, U.S.A.) were added to each of the bottles. They were then stoppered and shaken. When the floc had settled $1 / 3$ of the way down the bottle the iodine was released by the addition of $2 \mathrm{ml}$. of concentrated sulphuric acid. After the addition of $1 \mathrm{ml}$. of starch indicator to $200 \mathrm{ml}$. of this solution, it was titrated by burette with $.025 \mathrm{~N}$ phenylarsene oxide (Hach Chemical Company, Ames, Iowa, U.S.A.). Phenylarsene oxide is stable indefinitely and now replaces sodium thiosulphate in their method. The dissolved axygen concentration $\left(\mathrm{mg}_{0} \mathrm{O}_{2} / \mathrm{I}_{0}\right)$ is equal to the number of millilitres of phenylarsene oxide titrated. 


\section{$\underline{\text { Biological Oxygen Demand (BOD) }}$}

Samples were collected from the secondary tank overflow of the model lagoon. They were analyzed according to the procedure described in Standard Methods (39), but with the following modifications.

Nitrification was eliminated in the BOD bottles by the addition of $\mathrm{NH}_{4} \mathrm{Cl}$ 。 Ten millilitres of a $3 \mathrm{M} \mathrm{NH}_{4} \mathrm{Cl}$ solution were added to a 300 $\mathrm{ml}$. BOD bottle resulting in a $0.1 \mathrm{M} \mathrm{NH}_{4} \mathrm{Cl}$ concentration. Siddiqui et al (40) have shown that nitrifiers in the presence of $0.1 \mathrm{M} \mathrm{NH}_{4} \mathrm{Cl}$ do not convert ammonia to nitrate. To prevent șeve re immediate oxygen demand in the BOD bottles it was necessary to prepare the $3 \mathrm{M} \mathrm{NH}_{4} \mathrm{Cl}$ solution the day before the BOD test was started. The immediate oxygen demand of the $\mathrm{NH}_{4} \mathrm{Cl}$ solution could possibly be explained by an impurity in the $\mathrm{NH}_{4} \mathrm{Cl}$ reagent (41)。

To eliminate respiration by Daphnia during a bloom on day 148 these zooplankters were removed from the sewage sample by passing the sewage effluent through a 200 wire mesh filter.

The dissolved oxygen concentrations in the BOD bottles at zero time and after five days were measured by the modification of the azide modification of the iodometric method described in the previous section.

Total Suspended Solids

Total suspended solids was obtained by membrane filtration of known volume of secondary effluent. The filter was weighed before filtration. After filtration it was dried at $103^{\circ} \mathrm{C}$ for 1 hour 
and then reweighed (39). A Sartorius balance ${ }^{*}$ was used in these determinations.

Metrical filters (Gelman Instruments Company, Ann Arbor, Michigan, U. S. A.) with a pore size of $0.45 \mu$ were used. Since these filters were found to lose some weight during the drying process $(<0.1 \mathrm{mg}$ ) a control filter with no suspended solids was dried with the test filter. The weight lost by the control filter was then added to the weight of the suspended solids on the test filter to account for loss of weight of the test filter. The filters were stored in a dessicator over calcium chloride between tests.

The choice of sample size (either $50 \mathrm{ml}$. or $100 \mathrm{ml}$ ) depended upon the concentration of suspended matter in the sample. The sample size was chosen to ensure passage through the filter within 1 hour.

On days 152 and 158 during the Daphnia bloom the concentration of suspended solids excluding the Daphnia was obtained by passing a known volume of secondary effluent through a $200 \mu$ wire mesh filter. The filtrate was then tested in the regular manner for suspended solids.

Chemical Oxygen Demand (COD)

Analysis for $C O D$ was carried out according to the method described in Standard Methods (39), with the following exception. The Sartorius-Werke GMBH, Gottingen, West Germany 
0.25 $\mathrm{N}$ ferrous ammonium sulphate titrant usually used was replaced by the same solution which had been stabilized by the addition of cadmium (Hach Chemical Company, Ames, Iowa, U.S.A.) thus eliminating standardization before each test. The $20.0 \mathrm{ml}$. samples were collected from the overflow of the secondary cell.

Nitrate and Nitrite

This procedure was based on the method of Morris and Riley (42). Two separate determinations were carried out. The first procedure measured $\mathrm{NO}_{3}{ }^{-}+\mathrm{NO}_{2}{ }^{-}$concentration in the sample. The second procedure measured only $\mathrm{NO}_{2}{ }^{-}$concentration. The amount of $\mathrm{NO}_{3}{ }^{-}$in a sample was then determined by subtraction.

In the first procedure the $\mathrm{NO}_{3}{ }^{-}$in the water sample was reduced quantitatively by the addition of cadmium. The $\mathrm{NO}_{2}{ }^{-}$thus produced plus the $\mathrm{NO}_{2}{ }_{2}^{-}$already present in the sample was then measured spectrophotometrically by diazotizing with 1-napthylaminesulphanilic acid.

The second procedure was identical to the first except the cadmium reduction was omitted permitting only the $\mathrm{NO}_{2}{ }^{-}$already present in the sample to be measured.

The method of Morris and Riley was modified as follows (43).

Nitrate plus Nitrite

A standard curve for $\mathrm{NO}_{3}{ }^{-}+\mathrm{NO}_{2}^{-}$was constructed by filling 
a $28 \mathrm{ml}$. sample bottle with $25.0 \mathrm{ml}$. of known concentrations of $\mathrm{NO}_{3}$ $\left(0.1-2.0 \mathrm{mg} \cdot \mathrm{1}_{0}\right)$ which had been prepared in glass distilled water. Then one powder pillow of "Nitra Ver IV" (Hach Chemical Company, Ames, Iowa, U. S, A.) was added to the sample bottle and a timer was started. One "Nitra Ver IV" powder pillow contains the correct amount of cadmium and indicator for one test. The standard was shaken vigorously for one minute. It was then left standing for a further two minutes and subsequently, decanted into a cuvette with a $16 \mathrm{~mm}$. light path. After another 4 minutes the percent transmittance was measured at $520 \mathrm{~nm}$ using a Coleman Junior II A spectrophotometer* . The spectrophotometer was set to $100 \%$ transmittance using a $0 \mathrm{mg} \cdot-\mathrm{NO}_{3}{ }^{-} / 1$ : blank prepared with glass distilled water in exactly the same manner as the standards. The standard curve was plotted as the log of percent transmittance against the known $\mathrm{NO}_{3}{ }^{-}$concentrations.

All glassware was washed three times in glass distilled water to prevent $\mathrm{NO}_{3}{ }^{-}$or $\mathrm{NO}_{2}{ }^{-}$contamination.

Sewage samples were collected from the secondary effluent of the model sewage lagoon. They were analyzed in exactly the same manner as the standard solutions except that they were first passed through a $0.45 \mu$ Metricel filter. Also, dilutions of the samples were made to bring the $\mathrm{NO}_{3}{ }^{-}+\mathrm{NO}_{2}{ }^{-}$concentration into the range of the standard curve $\left(0.1-2.0 \mathrm{mg} / 1_{0}\right)$. These dilutions also had the

"Coleman Instruments, Division of Perkin-Elmer Corporation, Maywood, Illinois, U.S.A. 
advantage of minimizing the error caused by the slightly colored sewage effluent. This was necessary because the blank solutions were made up using glass distilled water.

The settling period, of one minute, after vigorous shaking permitted the cadmium to settle out of the sample before it was decanted into the cuvette. This was important not only because it removed interferencé by suspended cadmium particles but also because it stopped the reduction of nitrate to nitrite at a known time. Thus even if all the nitrate was not reduced to nitrite by the cadium this error will be corrected for in the standard curve.

\section{Nitrite}

A standard curve for $\mathrm{NO}_{2}{ }^{-}$was constructed by filling a $28 \mathrm{ml}$. sample bottle with $25.0 \mathrm{ml}$. of known concentrations of $\mathrm{NO}_{2}^{-}(0.01$ $0.20 \mathrm{mg} / 1_{0}$ ) which had been prepared with glass distilled water. Then, one powder pillow of "Nitri Ver" (Hach Chemical Company, Ames, Iowas, U.S. A.) was added. One "Nitri Ver" powder pillow contains the correct amount of indicator for a single test. The standard was shaken vigourously for one minute. It was then left standing for a further nine minutes and subsequently decanted into a $16 \mathrm{~mm}$. light path cuvette. After another five minutes the percent transmittance was measured at $493 \mathrm{~nm}$ using a Coleman Junior II A spectrophotometer. The spectrophotometer was set to $100 \%$ transmittance using a blank prepared with glass distilled water in exactly the same manner as the standards. 
The standard curve was plotted as the $10 \mathrm{~g}$ of percent transmittance against the known $\mathrm{NO}_{2}{ }^{-}$concentrations.

All glassware was washed three times in glass distilled water to prevent $\mathrm{NO}_{2}{ }^{-}$contamination.

The sewage samples for $\mathrm{NO}_{2}{ }^{-}$analysis were collected, filtered, and diluted in the same manner as the $\mathrm{NO}_{3}{ }^{-}+\mathrm{NO}_{2}^{-}$samples. Analysis for $\mathrm{NO}_{2}{ }^{-}$concentration in the samples was carried out in exactly the same manner as for the $\mathrm{NO}_{2}{ }^{-}$standards.

Ammonia

Ammonia was measured in the secondary effluent of the model lagoon by direct Nesselerization (39). For this procedure a Coleman Junior II A spectrophotometer and cuvettes with a $16 \mathrm{~mm}$. light path were used.

Total Phosphate

Analysis for total phosphate was done according to the aminonaptholsulphonic acid method described in Standard Methods (39). Samples were obtained from the overflow of the secondary cell.

The reference blank for this test was made using secondary effluent in which the ammonium molybdate reagent was replaced by an equal amount of a strong acid solution. With this reference solution a Coleman Junior II A spectrophotometer set at $6.90 \mathrm{~nm}$ and using a light path of $1 \mathrm{~cm}$. was set to $100 \%$ transmittance. 
This minimized interference caused by the slightly coloured sewage effluent. It was necessary to make this correction as the standard curve was constructed using known concentrations of orthophosphate in glass distilled water.

NTA Analysis

A gas chromatographic method, developed by Murray and Poveledo, was used to analyze for NTA concentration in the secondary effluent (44)。

One hundred milliliter samples of secondary sewage effluent were centrifuged at 9,000 r.p.m. for 20 minutes in a Sorvall RC 2 centrifuge* The sample was then drawn through a $0.45 \mu$ Metricel filter. It was acidified with $0.8 \mathrm{ml}$. concentrated hydrochloric acid and stored frozen until analysis. The samples were thawed, in warm tap water, immediately prior to analysis.

In brief, the analysis was carried out by freeze drying a known volume of the NTA sample in glass ampoules. After the addition of $1 \mathrm{ml}$. of methanol $\mathrm{HCl}$ reagent and $0.2 \mathrm{ml}$. of dimethyl sulphite the ampoules were sealed and esterified at $68^{\circ} \mathrm{C}$ for 3 hours. In this way the trimethyl ester of NTA was synthesized. After flash evaporation of the NTA sample $20 \mu l$ of internal standard (0.65 $\mathrm{mM}$ methyl heptadecanoate) was added to the ampoule. The NTA sample and the internal standard were then dissolved in a 150 pl of chloroform. This solution was injected into a Perkin-Elmer 900 gas chromatograph ${ }^{*}$ equipped with flame *Ivan Sorvall Incorporated, Norwalk, Connecticut, U.S.A. * *Perkin-Elmer Instruments Division, Norwalk, Connecticut, U.S.A. 
detectors and glass columns packed with $2 \%$ ethyIene glycol adipate coated with Chromosorb No The output was recorded on $x$ HewlettPackard recorder (model 7127 A) $\%$ fitted with a disc integrator: The ratio of the area of the NTA peak to the internal standard peak: was computed.

A calibration curve was constructed by plotting the ratio of peak areas of known NTA concentration to the internal standard against known concentration of NTA. The concentration of the sample was read off this curve.

Duplicate trials were carried out for each sample analysis. If the ratios calculated from these trials agreed to within $10 \%$ they were averaged and this value was used to read off the NTA concentration in the sample.

This method was not capable of analyzing for NTA concentration in the raw sewage influent because of interfering peaks as a result of unidentified components of the raw sewage

Hewlett-Packard, Palo Alto, California, $\mathrm{U}_{\alpha} \mathrm{S}_{\alpha} \mathrm{A}_{\alpha}$ 
RESULTS AND DISCUSSION 


\section{RESULTS AND DISCUSSION}

A sewage lagoon is an extremely heterogenous biologicalchemical system. Therefore, one could apply a wide variety of tests in an attempt to describe its performance. However, most lagoons are managed by engineers who recognize only that restricted battery of tests upon which they have relied throughout the years. These tests provide what is apparently a valid, but more importantly a useful index of a sewage facility's efficacy. Therefore, due to the constraints of time and a decision to practically relate the model's operational characteristics to that of the real lagoon, observation has been confined to the standard tests. Further, the Metropolitan Corporation of Greater Winnipeg conducted similar tests on the Charleswood Lagoon in 1968-69 (37), enabling a direct comparison of data.

\section{Retention Times}

The theoretical retention time of a sewage lagoon is the time required for the total volume in the lagoon to be exchanged. It is calculated by dividing the raw sewage influent rate into the total volume of the lagoon.

The theoretical retention time of the Charleswood AirAqua system is 30 days (37). The model lagoon had a total volume of 142 gallons and a raw sewage influent rate of 12. $4 \mathrm{ml}$./min. Thus its theoretical retention time was also 30 days. 
However, the effective retention times of these lagoons are much shorter. This is due to mixing in the lagoons set up by the aeration bubbles, and by wind in the Air-Aqua system. The time taken from the introduction of dye into the raw sewage influent until its appearance in the seconary effluent would appear to be a close approximation of the effective retention time.

The results of the Metro tests on the Air-Aqua system indicated that 24 hours after introduction of fluorescein dye its concentration in the secondary effluent was sufficient to be detected by a fluorometer.

This data suggests that the effective retention time in the Air-Aqua system was 24 hours. However, this was probably an overestimation of the effective retention time since Metro stated in their report that "the tests conducted are considered to be of limited relevance due to problems of photochemical decay and absorption of the fluoresence" (37).

Therefore, to obtain a better estimate of the effective retention time of the model lagoon nigrosin dye was employed since it will not photochemically decay. Also, the model lagoon was filled with tap water instead of sewage to prevent masking of dye color. The dye was detected by a KlettSummerson Photoelectric Colormeter in the secondary effluent 6 hours after its introduction. This suggests that the effective retention time of the model lagoon was 6 hours. Visually, it was observed in both lagoons that the dye moved down the primary cells in a slowly advancing front. 
Thus, in both cases at the time the dye was first detected in the secondary effluent (the effective retention times), most of the dye was still advancing down the primary cells. Movement of the dye through the model lagoon is shown in plate 1.

A direct comparison of the data suggest that the AirAqua system had an effective retention time four times Ionger than the model lagoon. However, this value is probably high because of the inaccuracies of the Metro method described above. In any case, this difference in effective retention times did not appear to have any adverse effect on the performance of the model lagoon since tests for $B O D$ and suspended solids were lower than for the Air-Aqua system. COD values were also low. Thus, even though the model lagoon had a shorter effective retention time it functioned more efficiently than the real lagoon. This seeming anomaly is discussed further in the section dealing with the efficiency of sewage treatment.

$\underline{\mathrm{pH}}$

The $\mathrm{pH}$ of the primary and secondary cells of the model lagoon during its operation is shown graphically in Fig. 1.

The average $\mathrm{pH}$ in the primary cell of the model lagoon was found to be 7.9 , with a range of $7.5-8.2$. The $\mathrm{pH}$ of the secondary effluent ranged from $7.5-8.1$ and averaged 7.8. The $\mathrm{pH}$ of the secondary effluent of the Air-Aqua system ranged from $7.6-8.0$ and averaged 7.7 (37). The close agreement of the average $\mathrm{pH}$ of the secondary effluents of the two lagoons 
would be a factor in the selection of a typical microbial population in the model lagoon.

The $\mathrm{pH}$ in both cells of the model lagoon appeared to oscillate around the average values at all temperatures tested. During periods of adjustment, when the lagoon temperature was changed, or, when the lagoon was starting up, there was invariably a slight rise in $\mathrm{pH}$ (Fig。1)。 This $\mathrm{pH}$ rise was probably a manifestation of physiological changes and/or a shift in the lagoon microbial population. This same phenomenon was observed during equalization of an unaerated portion of the Charleswood Lagoon coincident with the spring thaw (45).

Total Phosphate

Total phosphate was measured in the secondary effluent of the model lagoon. The results are shown graphically in Fig。2。

The average total phosphate concentration in the secondary effluent of the model lagoon was found to be $23.1 \mathrm{mg} / 1$. In the secondary effluent of the Air-Aqua system during a 21 month study from January 1968 to September 1969 the average total phosphate concentration was $30.5 \mathrm{mg} / 1_{\text {. However, for }}$ two reasons, it is likely that the total phosphate concentrations in the Air-Aqua effluent was actually lower than $30.5 \mathrm{mg} . / 1 /$ during the winter of 1970-1971 when the model lagoon was operating. 
A government directive effective August 1970 limited the phosphorus content in detergents to $20 \%$ by weight expressed as phosphorus pentoxide (46). This should have resulted in a lowering in the phosphate concentration in the Air-Aqua effluent from its average of $30.5 \mathrm{mg} / 1_{0}$ to approximately $28 \mathrm{mg} / 1_{\circ}$ This value was calculated taking into account that $16.9 \%$ of the phosphate was found to be removed by the Air-Aqua system (37). Also, during the winter of 1970-1971, detergents containing NTA were being marketed. During this period NTA in sewage probably reached a peak in concentration since these detergents were being promoted at this time. This would have had the effect of brining the Air-Aqua effluent total phosphate concentration into even closer agreement with the value obtained from the model lagoon. The constancy of total phosphate concentrations (Fig。2) in the model lagoon effluent was also noted by Metro in their report on the Air-Aqua system (37). This is likely a reflection of a fairly constant level of phosphate in raw sewage influent of both lagoons since the Charleswood Sewage Lagoon serves mainly a residential area.

$\underline{\text { Inorganic Nitrogen }}$

Inorganic nitrogen was monitored in the secondary effluent of the model sewage lagoon (Fig.3)。 Between days 88 and 131 the average $\mathrm{NO}_{3}{ }^{-}-\mathrm{N}$ concentration was $21.6 \mathrm{mg} / 1_{\circ}$ The average $\mathrm{NO}_{2}{ }^{-}-\mathrm{N}$ concentration was $0.4 \mathrm{mg} / 1$. Exact values for $\mathrm{NH}_{3}-\mathrm{N}$ 
in the secondary effluent could not be obtained since it is believed that the Nesslers reagent also reacted with dissolved organic nitrogen present in the samples. This resulted in the formation of brown precipitate which interfered with the spectrophotometry. Using this method, the average $\mathrm{NH}_{3}-\mathrm{N}$ concentration during this period was found to be approximately $5 \mathrm{mg} \cdot-\mathrm{N} / \mathrm{I}$.

Days 88 to 131 were selected as being the most typical for inorganic nitrogen concentration since inorganic nitrogen was not measured before day 88 and because after day 131 an algal bloom coincident with the change in lagoon temperature from $0.5^{\circ} \mathrm{C}$ to $15^{\circ} \mathrm{C}$ reduced the inorganic nitrogen concentration to about $10 \%$ of its previous average value (Fig. 3). The best estimate of the average inorganic nitrogen concentration can be obtained if the data during the algal bloom is not included in the calculation of the average value since these values would be incorrectly weighted. This is because algal blooms appear only periodically during the summer months in the AirAqua system.

The average inorganic nitrogen concentration of the model lagoon effluent is therefore estimated to be $27 \mathrm{mg} \cdot-\mathrm{N} / 1$. This is compared to an average of $24 \mathrm{mg} \cdot-\mathrm{N} / 1$. for the Air-Aqua system (37)。

The high $\mathrm{NO}_{3}{ }^{-}$concentration in the model lagoon likely occurred as a result of a dissolved oxygen concentration which was sufficient to select for a population of nitrifiers. This is a typical phenomenon in well aerated sewage lagoons (40). The 
fact that nitrifiers were present can be demonstrated by their interference with the $B O D$ test as described in the next section.

Biological Oxygen Demand (BOD)

$B O D$ was determined on the secondary effluent of the model lagoon (Fig.4)。

Nitrification is common in well aerated sewage treatment systems (40). This presents a problem in BOD determinations since they are supposed to reflect biological oxidation due to biodegradation of organic compounds. Nitrification in the model lagoon resulted in erroneous $B O D$ readings from days 44 to 72 . This problem was rectified after day $72(40)$. The effect of nitrification on the BOD test we.s demonstrated on day 72 by running duplicate samples with and without correction for nitrification (Fig. 4). The BOD test run without correction for nitrification gave an erroneous result of $40 \mathrm{mg}$ - $-\mathrm{BOD} / \mathrm{l}$. With correction for nitrification the actual BOD was $26 \mathrm{mg}$. $\mathrm{BOD} / 1$ 。

The average BOD in the effluent of the model lagoon for all the temperatures tested was $22.6 \mathrm{mg}$ - $-\mathrm{BOD} / \mathrm{I}_{\text {. }}$ This value is calculated without the results of tests between days 40 to 72. It also does not include a test on day 134. The BOD at this time could not be measured because of high algal respiration in the BOD bottles.

The average $B O D$ of the raw sewage influent during the pexiod the model lagoon was operating (Nov. 1970 to April 
1971) was $253 \mathrm{mg}$ - BOD/1. (47). Thus, the model lagoon had an average BOD removal efficiency of $91 \%$. This can be compared to a design efficiency for the Charleswood Air-Aqua of $90 \%$.

The average efficiency of BOD removal for the Air-Aqua system during the winter of 1970 - 71 was calculated to be $85 \%$ (47)。 A 21 month average BOD removal efficiency during 1968 - 1969 in the Air-Aqua system was $80 \%$ (37). During this time the $B O D$ of the raw sewage influent averaged $175 \mathrm{mg} \cdot-\mathrm{BOD} / \mathrm{I}_{\circ}(37)$. The large variation of the $r a w$ influent $B O D$ mentioned above is a reflection of atmospheric precipitation which is present in raw sewage during summer, since the area serviced by the Charleswood Lagoon has an incomplete storm sewer system. Thus the average yearly BOD of raw sewage is lower than the average BOD of raw sewage during winter.

Chemical Oxygen Demand (COD)

The values for COD in the secondary effluent of the model sewage lagoon appear in Fig。 5.

Since the COD test measures both biodegradable and non biodegradable compounds the absence of a COD peak between days 40 and 72 suggests that the BOD removal during this time was not abnormally low. This gives further credence to the assumation that the increase in the observed BOD during this period was a result of nitrification in the BOD bottles. The BOD in the model lagoon effluent during this period was probably close to the calculated average mentioned in the previous section. 
An algal bloom appeared in the secondary cell of the model lagoon after the temperature was changed from $0.5^{\circ} \mathrm{C}$ to $15^{\circ} \mathrm{C}$ (Fig. 7). This was followed by a bloom of Daphnia. The high COD values on days 135 and 142 were coincident with and reflected the algal bloom (Fig. 5). Since most of the suspended matter present during the algal bloom was consumed by the Daphnia bloom which followed, it was expected that the COD on day 159 during the Daphnia bloom would be at least as great as during the algal bloom. However, this was not the case. This seeming anomally can possibly be explained as follows. In the presence of a good food source Daphnia can grow to a large size within 3 weeks and contain up to $23 \%$ fat (48). During this bloom some Daphnia magna reached a size of $4.0 \mathrm{~mm}$. The rapid growth and large size was probably a result of a good food source, Chlorella, which was one of the two dominant algae in the algal bloom. Also, reproducing Daphnia store fat prior to laying eggs and early in development these eggs contain a high fat content. At the time of this COD test many Daphnia contained eggs. Since long chain aliphatic compounds are not oxidized by the COD test (39) the absence of a COD peak during the Daphnia bloom can possibly be explained by their fat content.

The COD values obtained are indicative of an efficiently operating sewage treatment system, since the COD is usually approximately six times as high as the BOD (47). In this case the average $B O D$ was $22.6 \mathrm{mg}-\mathrm{BOD} / \mathrm{l}$. The average $\mathrm{COD}$ excluding 
the values obtained during the algal bloom was $86.1 \mathrm{mg}-\mathrm{COD} / \mathrm{l}$.

\section{Dissolved Oxygen}

Dissolved oxygen concentration in the model lagoon was not precisely controlled. However, dissolved oxygen was monitored periodically to ensure that it did not fall below $2.0 \mathrm{mg}_{0}-\mathrm{O}_{2} / \mathrm{I}_{0}(\mathrm{Fig}, 6)$ as the Charleswood Air-Aqua aeration system was designed to sustain a dissolved oxygen concentration of $2.0 \mathrm{mg} \cdot-\mathrm{O}_{2} / \mathrm{I}$. Also, tests have indicated that the dissolved oxygen tension which would affect the metabolic rate of activated sludge ranges from $0.4 \mathrm{mg} \cdot-\mathrm{O}_{2} / \mathrm{I}_{\text {. to }} 2.0 \mathrm{mg} \cdot-\mathrm{O}_{2} / \mathrm{I}_{0}$ (38). oxygen depletion in the primary and secondary cells coincident with a change in model lagoon temperature from $0.5^{\circ} \mathrm{C}$ to $15^{\circ} \mathrm{C}$ was remedied in the primary cell on day 107 by increasing the aeration pressure from $0.5 \mathrm{lb} . / \mathrm{in}_{0}{ }^{2}$ to $1 \mathrm{lb} . / \mathrm{in}^{2}$ (Fig. 6). This oxygen depletion was probably a result of the reduced solubility of oxygen at the higher temperature as well as an increased rate of microbial respiration. The dissolved oxygen concentration began to recover in the secondary cell after the increase in the air pressure. However, it fell once more to a new minimum probably as a result of an algal bloom which developed shortly after the elevation in temperature. In an effort to oxygenate the water in the secondary cell the lights in the lagoon room were left on continuously. When the dissolved oxygen concentration continued to fall, on day 121 the lights in the lagoon room were switched off. The oxygen tension recovered rapidly thereafter (Fig. 6). The depletion 
of dissolved oxygen during the algal bloom could have resulted from light levels close to the compensation point. Thus, during the time the lights were left on continuously the algae were not producing sufficient oxygen to compensate for the oxygen required for the decomposition of the large algal organic load (Fig. $5 \& 7$ ). After the lights in the lagoon room were shut off the lagoon only received illumination from a nearby window. Consequently, photosynthesis was reduced. The organic load on the secondary cell was diminished by a decrease in algal production enabling the dissolved oxygen concentration to recover (Fig. 6).

Except during the algal bioom in the secondary cell the oxygen tension in the secondary was always higher than in the primary cell. This was in spite of the tapered aeration system which delivered less aeration to the secondary cell. This was likely a manifestation of the greater organic load on the primary cell of the model lagoon.

Suspended Solids

Suspended solids that were present in the secondary effluent of the model sewage lagoon are shown graphically in Fig. 7 . The average suspended solids concentration was $10.0 \mathrm{mg} / \mathrm{I}$. The average suspended solids of the raw sewage influent during the period of operation of the model lagoon (Nov. 1970 to April 1971) was $445.4 \mathrm{mg} / \mathrm{I}$. Thus the efficiency of suspended removal was $98 \%$. The concentration of suspended solids in the secondary effluent of the Air-Aqua system during this 
same period was $27.1 \mathrm{mg} / 1$. Thus, the Air-Aqua system removed $93 \%$ of the suspended solids (47). The 21 month average suspended solid concentration in the Air-Aqua system during 1968 - 69 was $34 \mathrm{mg} / 1_{\text {。 }}$ During this period $82 \%$ of the suspended solids were removed (37)。

The low suspended solids in the secondary effluent of the model lagoon suggest that it may have been a successful "aerobicanaerobic" system. This can be concluded because the aeration system was sufficient to maintain adequate dissolved oxygen in the water column but it did not create enough agitation to prevent the settling of suspended solids. Sludge build-up was observed on the bottom of the cells where anaerobic breakdown is presumed to have occurred.

These data also clearly depict the phytoplankton bloom in the secondary cell from days 129 to 143 and the Daphnia bloom which followed (Fig. 7).

\section{$\underline{\text { Algal and Daphnia Blooms }}$}

The following algae were present in the secondary cell of the model lagoon on day 142 during the algal bloom:

Chlamydomonas sp., Scenedesmus acutus, Ochromonas sp., Ankistrodesmus falcatus, Selenastrum minutum, Synedra ulna and Chlorella sp. The last two mentioned species were most abundant. Chlamydomonas and Scenedesmus are indicators of high nutrient-content in water. Ochromonas, ingests particulate matter being phagotrophic as well as autotrophic. Thus, it is well suited to the environment of the model sewage lagoon 
especially since it requires vitamins as well as some amino acids for growth (49). The following algae have been also identified in the Charleswood Air-Aqua system: Chlamydomonas, Chlorella, Scenedesmus, and Ankistrodesmus (37). This suggests that the environment of the model lagoon may be similar to that of the Air-Aqua system.

A bloom of Daphnia pulex followed the algal bloom (Fig.7). This population was succeeded by a monoculture of Daphnia magna later in the Daphnia bloom. Daphnia pulex is well suited to the environment of a sewage lagoon. It can tolerate low oxygen tensions and is known to consume bacteria. Daphnia manna is also characteristic of sewage lagoons and it has been identified in the Charleswood lagoon. The Daphnia presumably were responsible for consuming the algal bloom as well as most of the other suspended matter present in the secondary cell of the model lagoon (Fig. 7).

Biodegradation of INA

The effect of temperature on the biodegradation of NTA is important in outdoor sewage treatment systems, exposed to severe, prolonged winters. The Charleswood lagoon is located in a 'Mid Continental' climate which has a mean daily temperature below $0^{\circ} \mathrm{C}$ for 5 months of the year (50). In 1968, the temperature of the Charleswood Air-Aqua system was below $10^{\circ} \mathrm{C}$ for 7 months of the year (37). It was less than $1^{\circ} \mathrm{C}$ for 3 months of the year. This period is of major importance since, in sewage lagoons, activity measured below $10^{\circ} \mathrm{C}$ is considered 
to be primarily due to psychrophilic microorganisms (6).

The concentrations of NTA that were present in the secondary effluent of the model lagoon at $15^{\circ} \mathrm{C}, 5^{\circ} \mathrm{C}$, and $0.5^{\circ} \mathrm{C}$ are shown in Fig. 8. The average value for NTA concentrations in the secondary effluent at $15^{\circ} \mathrm{C}, 5^{\circ} \mathrm{C}$, and $0.5^{\circ} \mathrm{C}$ were found to be 1. $0,7.7$, and $10.9 \mathrm{mg} \circ-\mathrm{NTA} / 1$. respectively。 Since $14.6 \mathrm{mg} \circ-\mathrm{NTA} / \mathrm{I}_{0}$ was added to the raw sewage influent, the average percent breakdown at these temperatures was $93 \%, 47 \%$ and $25 \%$ respectively。 Thus, for approximately 3 months of the year when the Charleswood Air-Aqua system is between $5^{\circ} \mathrm{C}$ and $1^{\circ} \mathrm{C}$ the NTA biodegradation efficiency of the lagoon would be expected to be less than $50 \%$. For another 3 months of the year NTA biodegradation efficiency would be reduced to approximately $25 \%$ since the lagoon temperature was less than $1^{\circ} \mathrm{C}$ for this period. These data do not include the concentration of NTA already present in the raw sewage influent since it was not possible to analyze for NTA in raw sewage because of unidentified components in the raw sewage which interfered with the gas chromatography。

Other tests have indicated that laboratory semicontinuous activated sludge systems, fed $10 \mathrm{mg}$ - NTA/1。 were able to degrade $80-85 \%$ of the NTA at $20^{\circ} \mathrm{C}$ and approximately $25 \%$ at $5^{\circ} \mathrm{C}$ in 1 day (30). Bouveng et al (35) found that a trickling filter was capable of removing $80-90 \%$ of the NTA in summer and fall under normal operating conditions. However, at $4^{\circ} \mathrm{C}$, NTA in batch cultures of sewage from this same treatment system was stated to have a half life in excess of 
one month.

The data in Fig. 8 agree with other investigations $(29,30$, $31,32,33$ and 34) with respect to the requirements of a period of acclimation before optimum NTA removal is attained. This is best demonstrated during the temperature shift from $0.5^{\circ} \mathrm{C}$ to $15^{\circ} \mathrm{C}$. Warming of the lagoon from $0.5^{\circ} \mathrm{C}$ to $15^{\circ} \mathrm{C}$ began on day 122. However, it was not until approximately 21 days 1ater that the NTA concentration in the secondary effluent reached its new plateau. This acclimation period may be the time required for a population shift in favor or organisms capable of degrading NTA at mesophilic temperatures.

Shumate et al (33), have found that at constant NTA feed levels, NTA removal in an activated sludge plant fluctuated around a mean value. This could possibly have occurred because of fluctuations in the population of the sewage treatment system. The population fluctuations could have resulted from variations in flow, sewage strength, or sewage components. Thus, if the population is constantly shifting, there will be a need for continuing acclimation of the population for the utilization of minor sewage components (such as NTA). If the acclimation rate is slower than the rate of population shift, it would be expected that the NTA removal would fluctuate about a mean value. This phenomenon was also observed in the model lagoon (Fig. 8) which was fed NTA at a constant level of $14.6 \mathrm{mg} \cdot-\mathrm{NTA} / 1$. The fluctuations were most pronounced at $5^{\circ} \mathrm{C}$ and $0.5^{\circ} \mathrm{C}$. The standard 
deviation of the values at these plateaus exceeded the standard deviation of values at the $15^{\circ} \mathrm{C}$ plateau (Fig. 8). The greater fluctuation of NTA breakdown at psychrophilic temperatures may occur as a result of a slower acclimation rate at lower temperatures. At $15^{\circ} \mathrm{C}$ the rate of acclimation may be rapid enough to reduce the fluctuations in NTA breakdown during population shifts. Shumate et al (33), have also found that the standard deviation of NTA removal increased with increasing NTA dosage.

The rate of NTA breakdown as a function of temperature is shown in Fig. 9. These rates were calculated from the data appearing in Fig. 8. "They are the average biodegradation rates for the temperatures tested. At $15^{\circ} \mathrm{C}, 5^{\circ} \mathrm{C}$, and $0.5^{\circ} \mathrm{C}$ the rates of NTA breakdown were $0.45,0.22$ and $0.12 \mathrm{mg} .-\mathrm{NTA} / \mathrm{I}_{0} /$ day respectively. These values are significantly lower than those calculated by Forsberg and Lindqvist (29). They stated that NTA biodegradation rates at $15^{\circ} \mathrm{C}, 10^{\circ} \mathrm{C}$ and $5^{\circ} \mathrm{C}$ were approximately 6,3 , and $1 \mathrm{mg}$ - $-\mathrm{NTA} / 1$./day respectively when bacterial cultures utilizing NTA as a carbon source were grown under optimal nutrient conditions.

Two bacterial cultures capable of utilizing $\mathrm{Na}_{3}$ NTA aerobically as a sole source of carbon and nitrogen were isolated from Charleswood Air-Aqua primary sewage by $\mathrm{Na}_{3} \mathrm{NTA}$ enrichment technique. These cultures were grown at room temperature on a basic salts medium plus $20 \mathrm{mg} \cdot-\mathrm{Na}_{3} \mathrm{NTA} / \mathrm{I}$. Growth studies indicated that they could not use $\mathrm{Na}_{3} \mathrm{NTA}$ anaerobically as a sole source of carbon and nitrogen. This 
is in agreement with other observations (12) which have shown that there was no NTA breakdown in laboratory digesters or septic tanks. Since unaerated lagoons rapidly become anaerobic after the formation of an ice cover (6), it can be expected that NTA biodegradation under these conditions would cease. Only 12 lagoons of 198 in the prairie provinces are aerated at this time. Biodegradation of NTA during winter in these lagoons would be expected to be nonexistent.

\section{Efficiency of Liagoon Sewage Treatment}

The efficiency of bacterial biodegradation is influenced by the physiological state of the bacterial population (51). This phenomenon can be observed in a chemosiat. At low dilution rates, (long retention times), there is a decreased efficiency of substrate removal (36). This can be explained by the senescence of the bacterial population and consequently, a reduction in their physiological activity, since they are not required to replenish their numbers rapidly. If a sewage lagoon operates in a manner similar to a chemostat, this same phenomenon may also be occurring since lagoons such as the Air-Aqua system and the model lagoon have long retention times (30 days). The efficiency of sewage treatment in these cases may be increased in two ways.

The retention time of the lagoon could be decreased. Thus, the bacterial population and bacteriostatic substances would be washed out at an increased rate. The result would be a population 
with an increased rate of reproduction. Consequently, it would be more active physiologically and would therefore process sewage more efficiently。 In fact, it appears that the Air-Aqua system and the model lagoon did operate at reduced efficiencies because of their long retention times. This can be explained as follows. The dispersion of the raw sewage from the influent end of the primary cell into the secondary effluent was approximately four times as fast in the model lagoon as in the Air-Aqua system. Thus, the effective retention time of the model lagoon was less. It can be expected, therefore, that if the efficiencies of these lagoons were being reduced by their long retention times that the model lagoon would be more efficient than the Air-Aqua system. In fact, this was the case, since the model lagoon had greater efficiencies of $3 O D$ and suspended solids removal than the Air-Aqua system (Table I). COD values were also low (Table I). In other words, the bacterial population in the model lagoon could have been more active physiologically than the population of the Air-Aqua system.

A second method to enhance the physiological state of a bacterial population, and hence its efficiency of substrate removal, is to introduce a predator into the system $(52,53)$. This has the same effect as decreasing the retention time of a sewage lagoon, since the self-limiting population of bacteria is removed by grazing. In the case of the model sewage lagoon, the importance of Daphnia, a bacterial consumer, can be demonstrated with respect to NTA breakdown. In Fig。10, the percent NTA breakdown, the suspended solids, and the percent 
suspended solids composed of Daphnia, are plotted against time. As the suspended solids increased, and the percent suspended solids composed of Daphnia increased, the percent NTA breakdom also increased. For example, on day 152 Daphnia constituted $94 \%$ of the total suspended solids which was $51 \mathrm{mg} / 1$. However, Daphnia grazing had actually lowered the suspended solids concentration, excluding Daphnia, to less than one-half the value present on day 143 (Fig. 10). Yet, the percent INTA degradation had actually increased by approximately $35 \%$ during this time.

This observation emphasizes the importance of bacterial predators to efficiency of sewage treatment. Therefore, attempts to ascertain the rates of bacterial biodegradation of sewage components in the absence of other members of this ecological community must be interpreted with caution. 


\section{GENERAI CONCLUSIONS}




\section{GENERAL CONCLUSIONS}

A secondary sewage treatment facility, such as a sewage lagoon, is designed to remove a large proportion of the biodegradable components of raw sewage. It is not, however, capable of removing a large portion of influent nutrients. Tests for $B O D$, COD, and suspended solids are therefore amongst the most important criteria for defining the operational characteristics of a secondary sewage treatment facility since, together, they provide an accurate picture of the efficiencies of breakdown of biodegradable carbon. On this basis, the model lagoon was slightly more efficient than the Charleswood Air-Aqua system. It removed a greater percentage of $B O D$ and suspended solids and its COD values were low. If one accepts the postulate that these three tests do accurately measure the efficiency of a sewage lagoon, then the model lagoon must be considered to represent a successful secondary treatment system. It therefore seems reasonable to conclude that it provided a valid means for testing the biodegradability of NTA in a sewage lagoon at the severe winter temperatures experienced in the Canadian prairie provinces.

The model lagoon also offers opportunities for several other lines of research. It would be a convenient system for the study of biodegradation of other selected compounds, since the temperature of the lagoon can be controlled at will and because large quantities of the compound to be tested are not required. 
It also presents an opportunity to conveniently study the biological community of a sewage lagoon. Such studies could include the effects of predator prey relationships on the efficiency of sewage treatment. NTA appears to be a promising replacement for tripolyphosphate as a detergent builder. To date, its presence in the environment at expected concentrations has not been found to be injurious to either human or animal health. In waterways and sewage treatment systems, under favourable conditions, NTA appears to be sufficiently biodegradable to warrant its use as a detergent builder. However, significant amounts of NTA (circa 10 mg. - NTA/1。) can be expected to be discharged from aerated sewage lagoons during winter. Also, if the effluent from unaerated lagoons is permitted to flow into receiving streams during winter, it can be expected that it would contain approximately $20 \mathrm{mg} \cdot-\mathrm{NTA} / \mathrm{I}$. since biodegradation is expected to be non-existent under the anaerobic conditions which prevail at this time. Thus, it would be prudent to initiate further research, at winter temperatures, into the biodegradation and effects of NTA in waterways which receive either raw sewage or effluent from sewage lagoons.

If NTA is used as a detergent builder, it would be a valuable asset for the reduction of the rapid eutrophication of many bodies of water, since if $100 \%$ of the detergent phosphate was replaced by NTA it could be expected that the average phosphate concentration in the model lagoon effluent would be reduced from $23.1 \mathrm{mg} \cdot-\mathrm{PO}_{4} / 1_{0}$ to approximately $7.9 \mathrm{mg} \cdot-\mathrm{P}_{4} / \mathrm{I}_{0}$ 


\section{TABLE I}

Comparison of the operational characteristics of the model lagoon and the Charleswood Air-Aqua system.

Test

Air-Aqua

Model Lagoon

Effluent pH

7. 7

7.8

Effluent Total Phosphate

$30.5 \mathrm{mg} \cdot-\mathrm{PO}_{4} / 1_{0} \quad 23.1 \mathrm{mg}_{\bullet}-\mathrm{PO}_{4} / 1^{\circ}$

Effluent Inorganic Nitrogen

24. $0 \mathrm{mg}$ 。 $-\mathrm{N} / \mathrm{I}_{\text {。 }}$

$27.0 \mathrm{mg} \cdot-\mathrm{N} / 1$.

BOD Removal Efficiency

$85 \% *$

$80 \% * *$

$91 \%$

Effluent COD

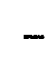

$86.1 \mathrm{mg} \cdot-\operatorname{COD} / 1$.

Suspended Solids Removal Efficiency

$93 \% *$

$82 \% * * *$

$98 \%$

* Values obtained from Nov. 1970 to April 1971

**Values obtained from Jan. 1968 to Sept. 1969. 
Plate 1 Frontal view of the model sewage lagoon: A, before introduction of nigrosin dye into the influent; $B, 55$ minutes after introduction; and $C, 6.5$ hours after introduction. 


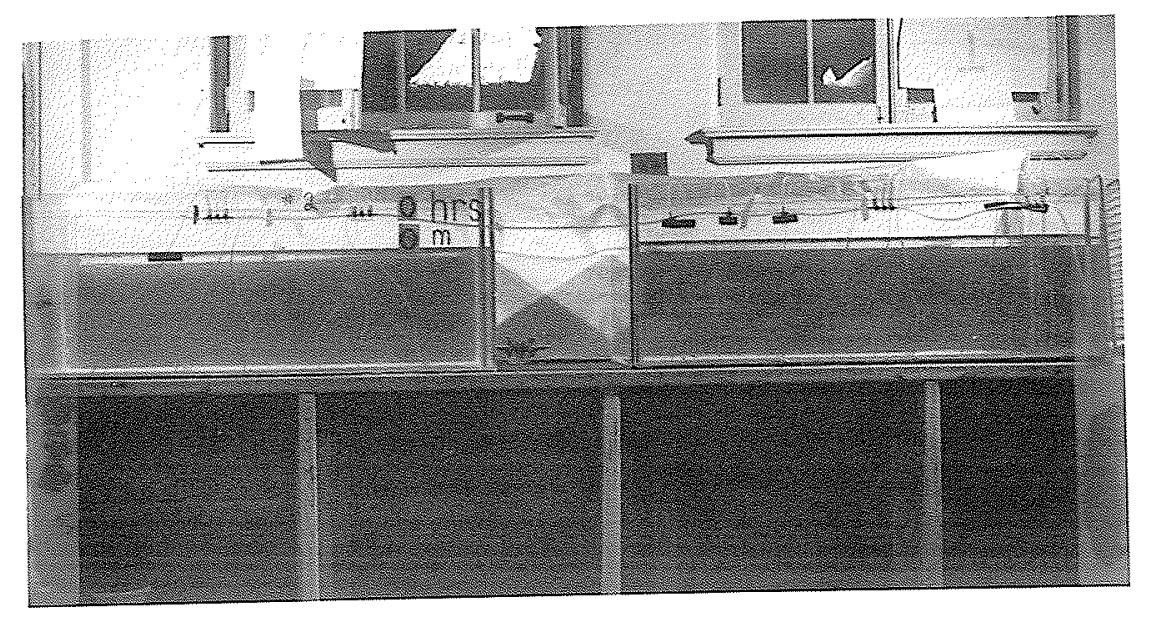

A
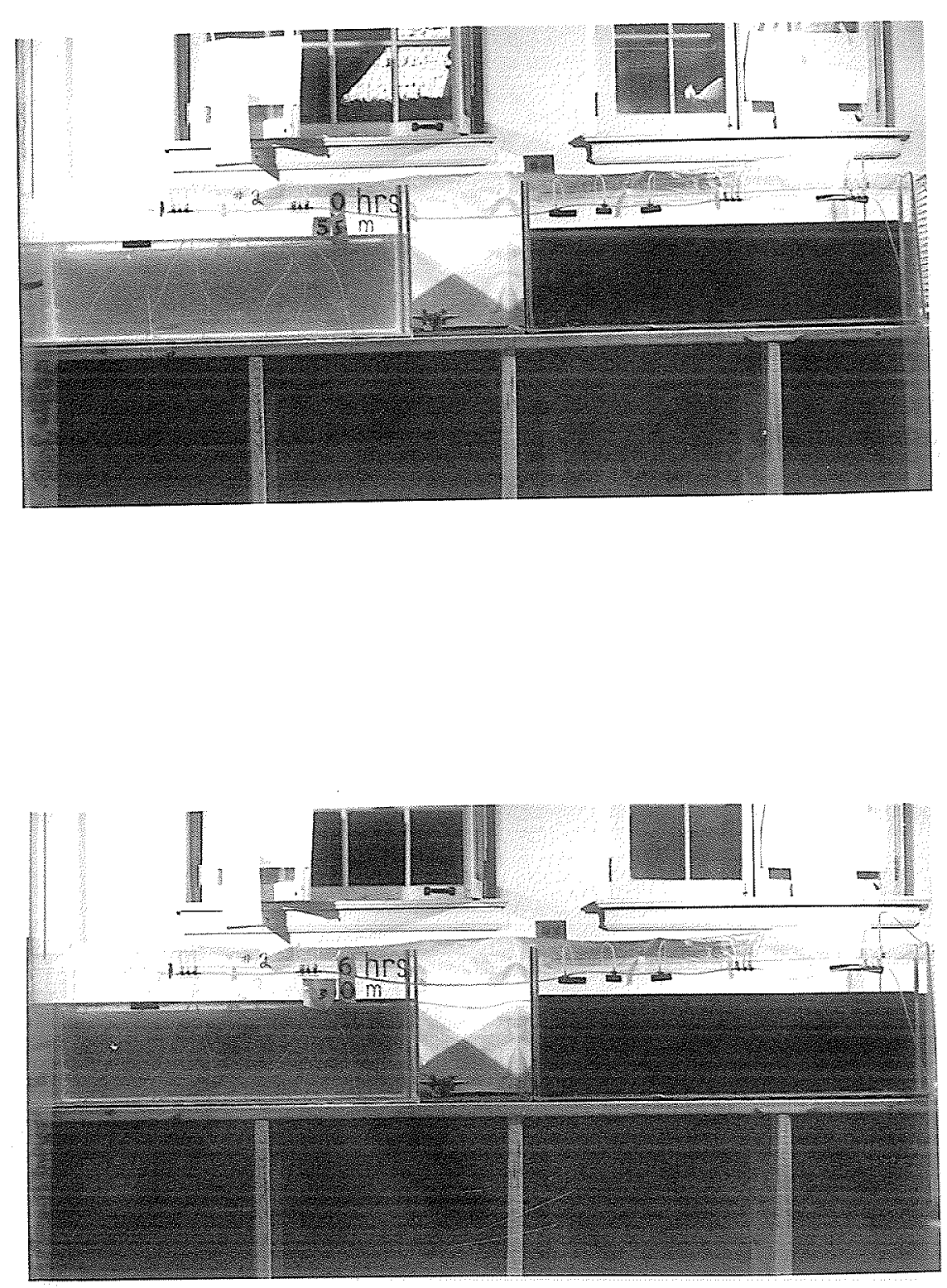

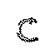


Fig. $1 \quad \mathrm{pH}$ at the effluent opening of the primary cell of the model lagoon, open circles; $\mathrm{pH}$ in the secondary effluent solid circles (see page 33 ). 


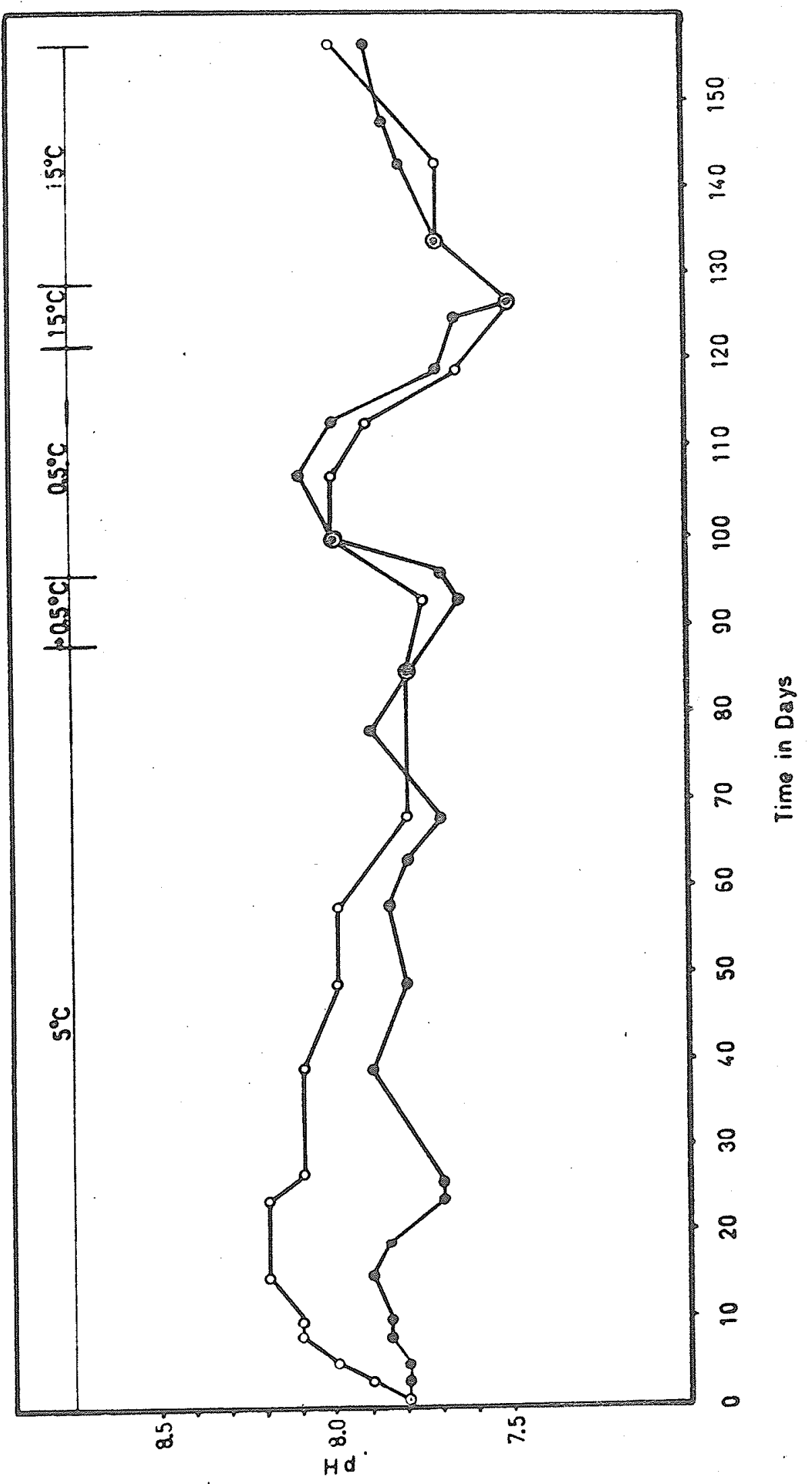


Fig. 2. Total phosphate concentration in the secondary effluent of the model lagoon (see page 34). 


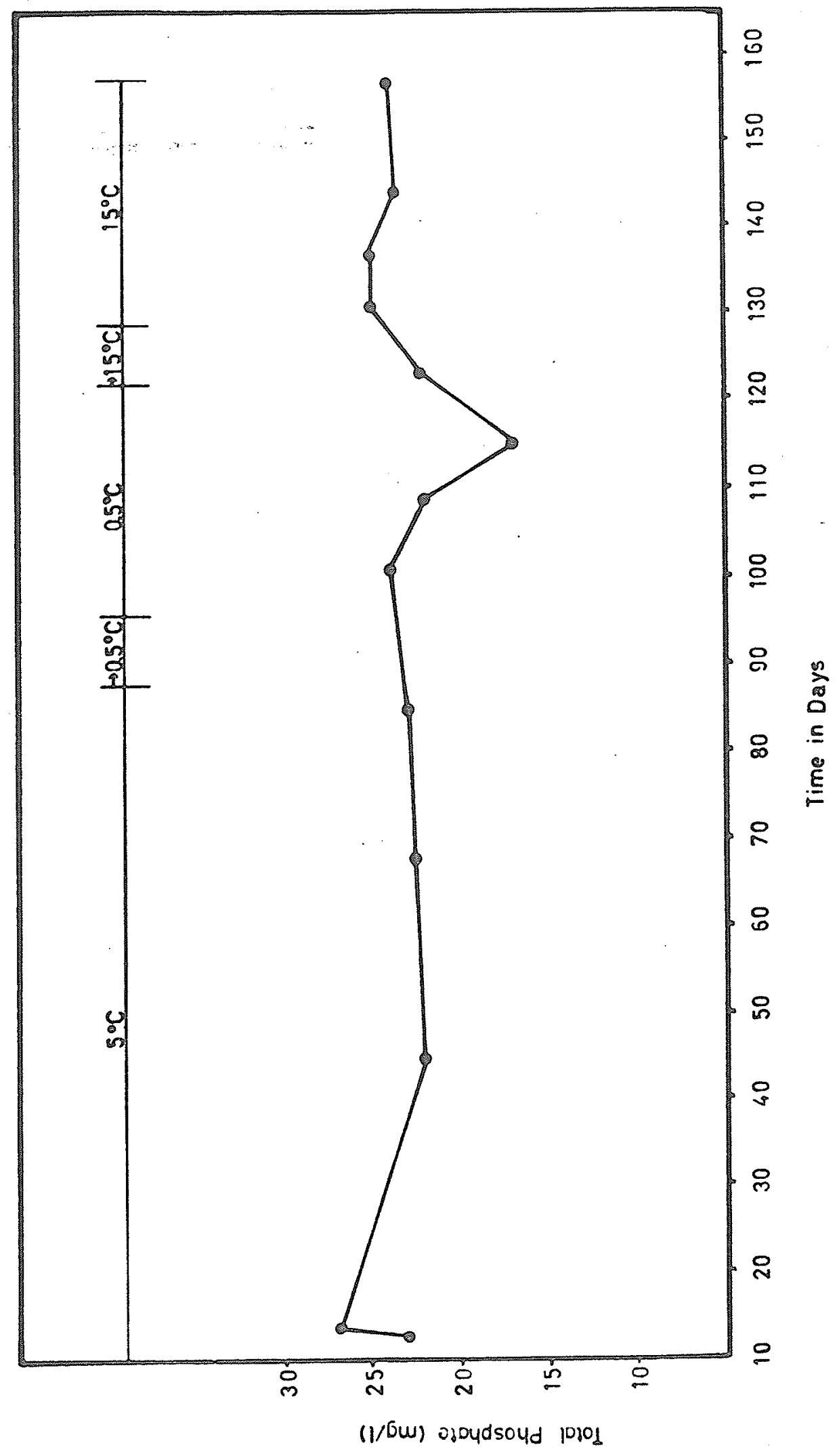


Fig. 3. Nitrate-N concentration, solid circles; and nitrite-N concentration, open circles, in the secondary effluent of the model lagoon (see page 35). 


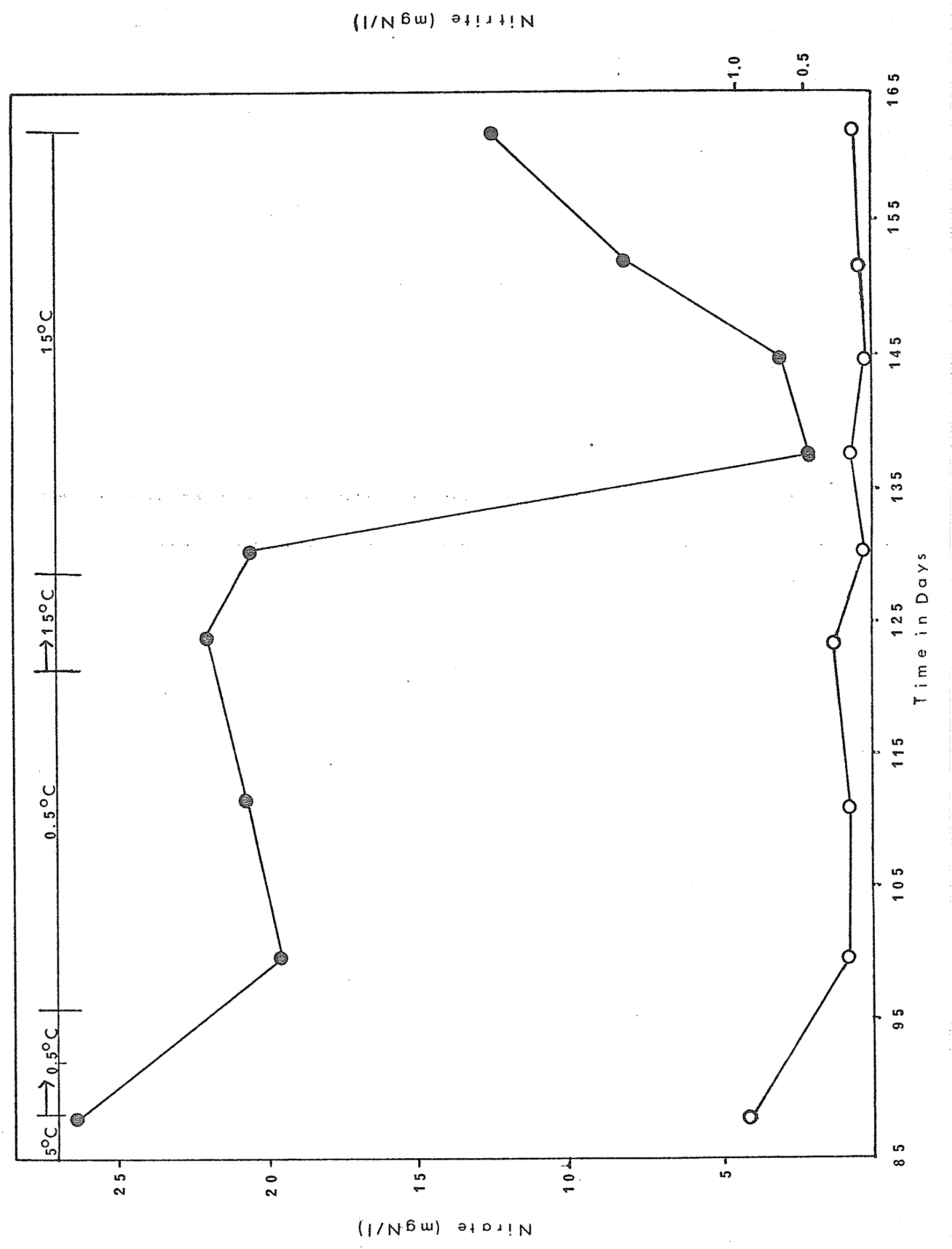


Fig. 4. BOD in the secondary effluent of the model lagoon, without correction for nitrification, closed circles; with correction for nitrification, open circles. Broken line denotes period during which BOD could not be measured because of interference by an algal bloom (see page 37 ). 


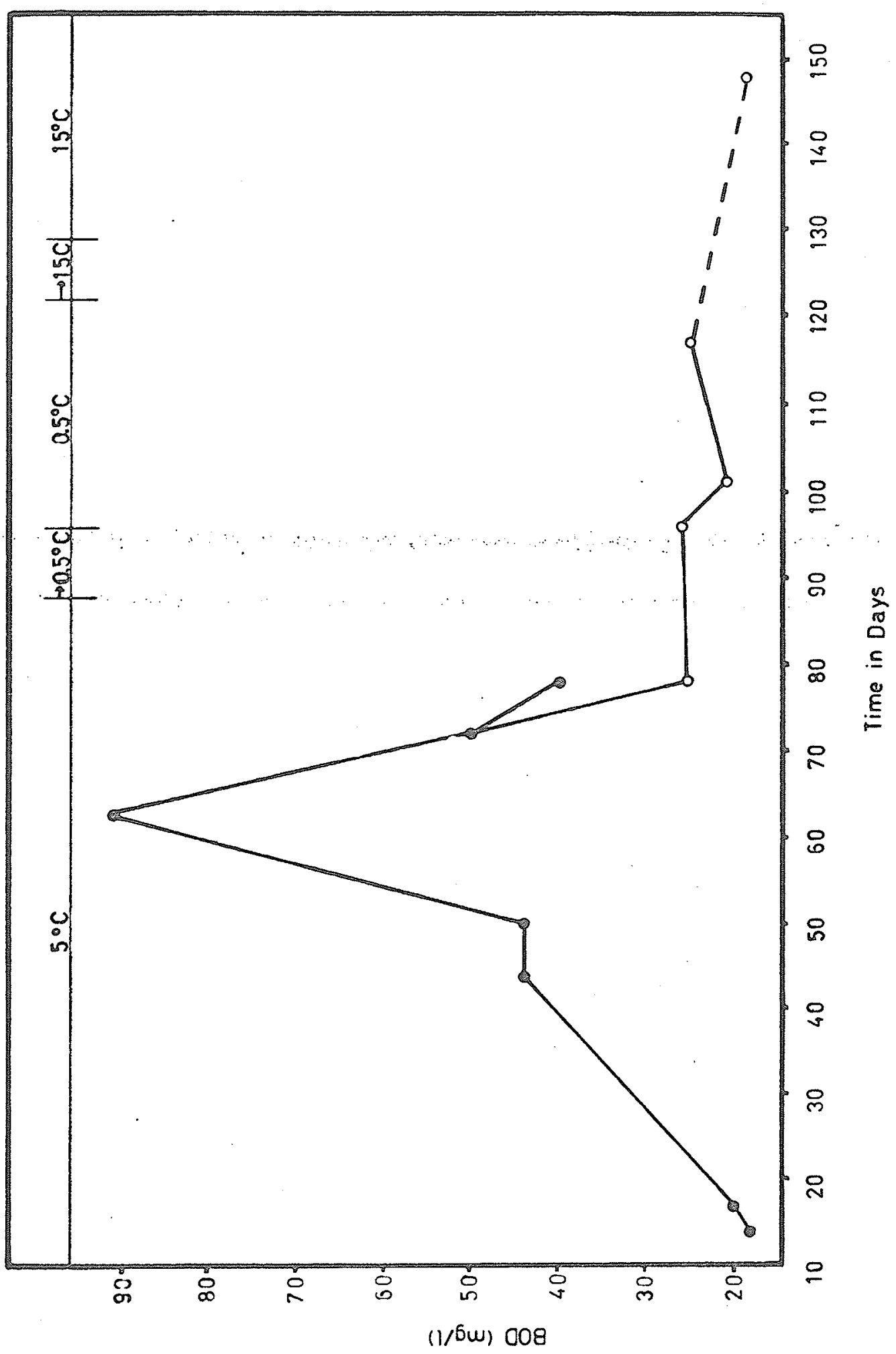


Fig. 5 COD of the secondary effluent of the model lagoon (see page 38). 


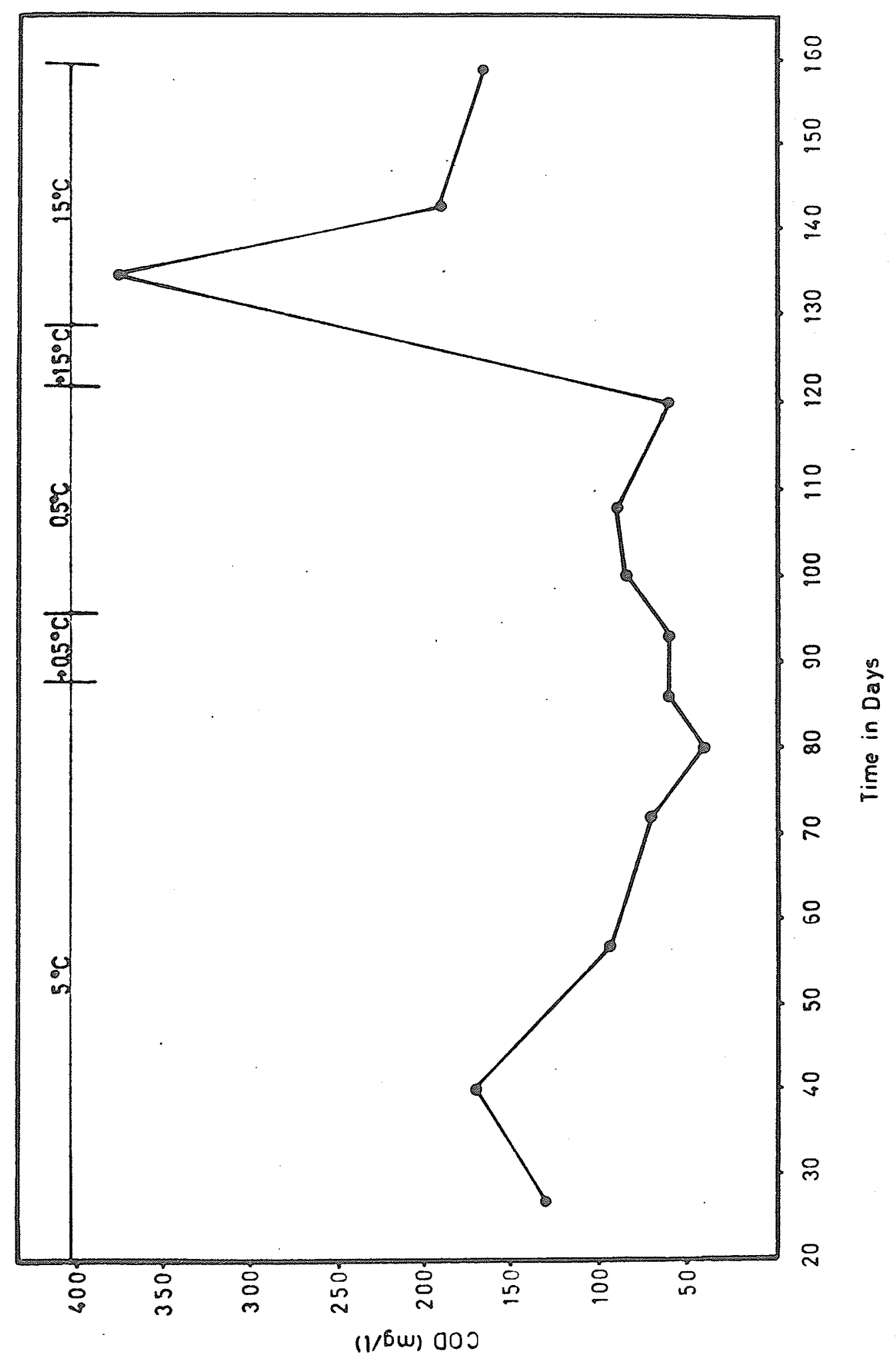


Fig. 6 Dissolved oxygen concentration in the model lagoon; primary cell solid circles; secondary cell open circlës (see page 40 ). 


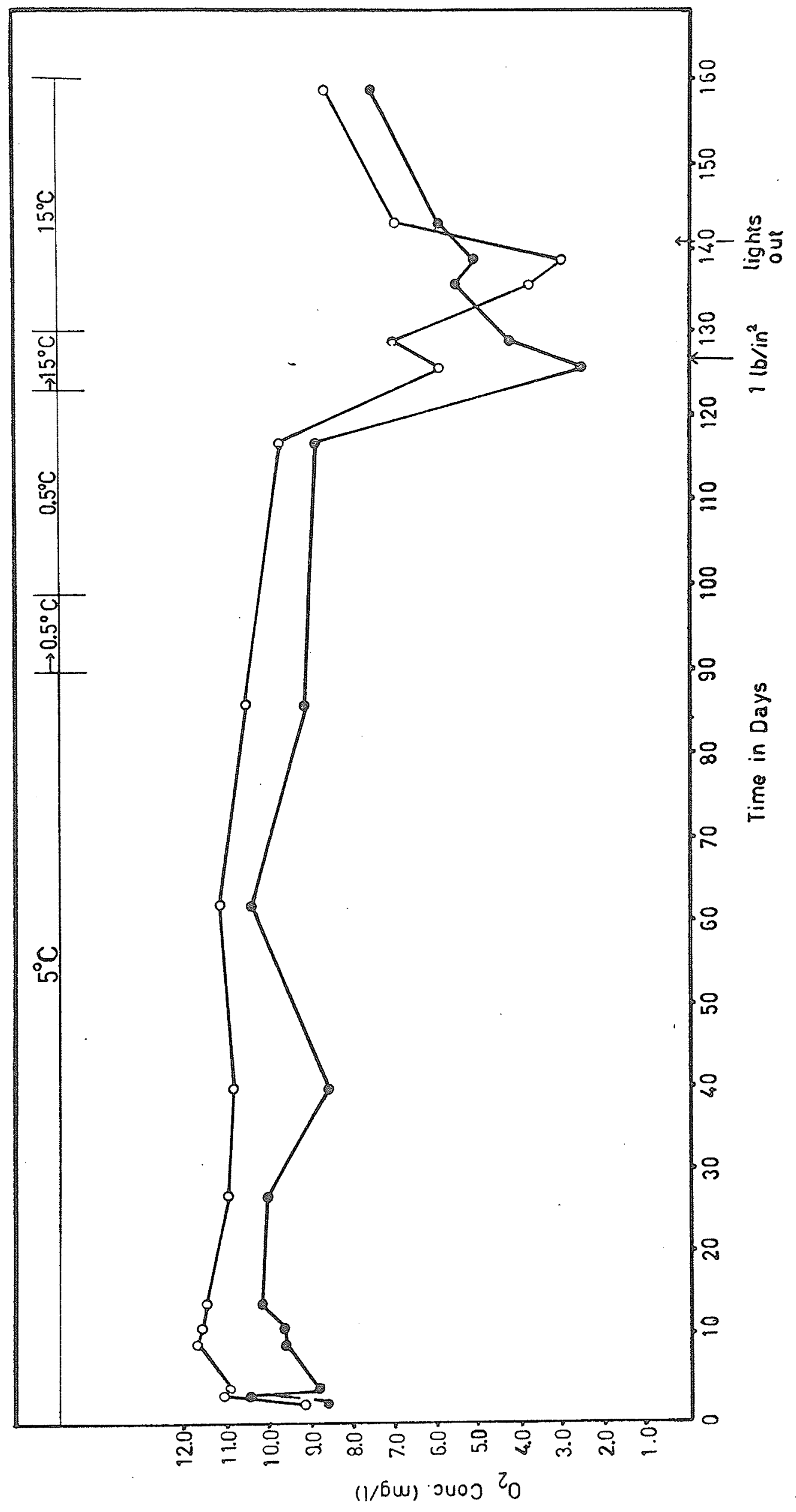


Fig. 7. Total suspended solids in the secondary effluent of the model lagoon, solid line. Suspended solids concentration excluding Daphnia in the secondary effluent of the model lagoon, broken line (see page 41). 


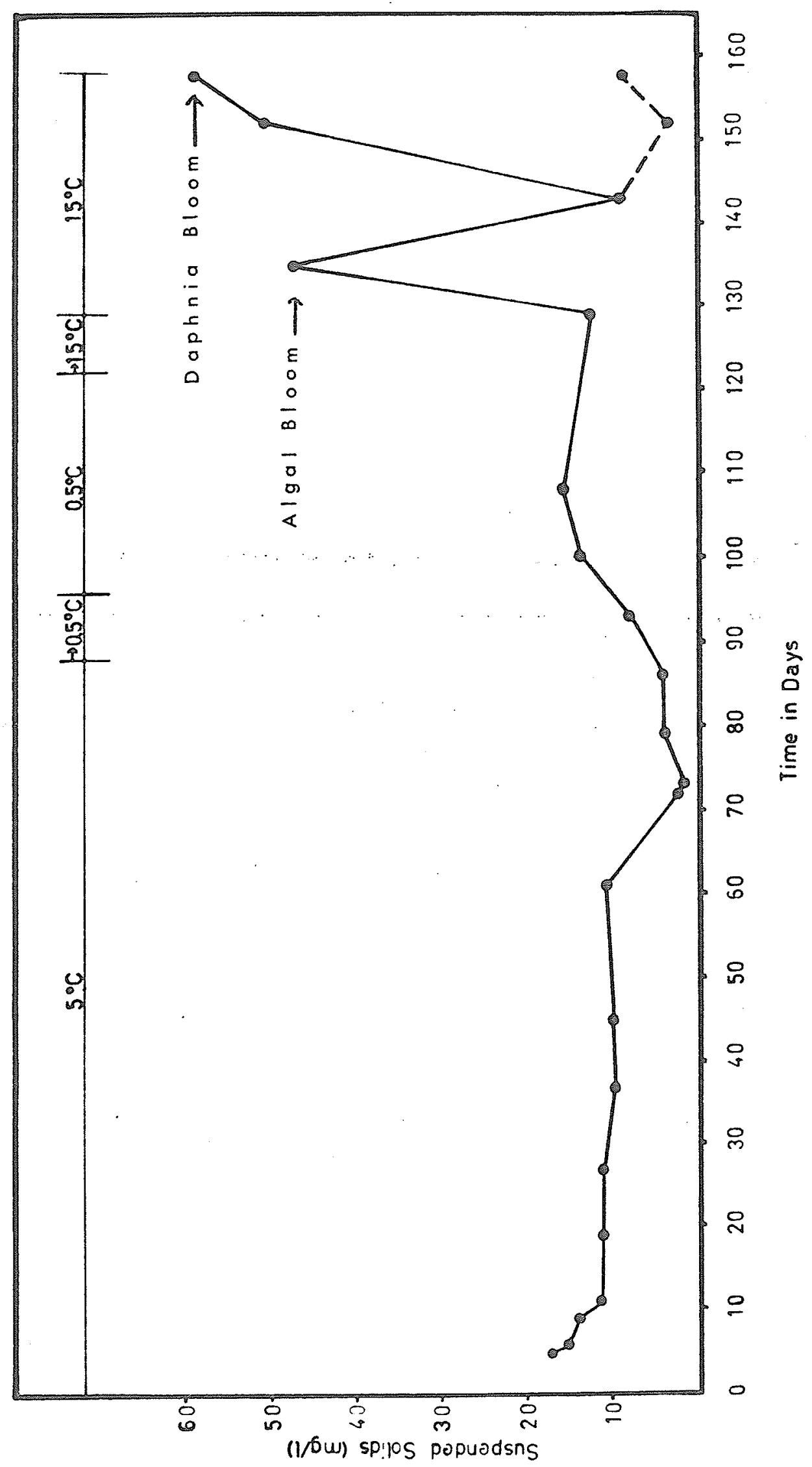


Fig. 8. Concentration of acid NTA in the secondary effluent of the model lagoon (see page 44). 


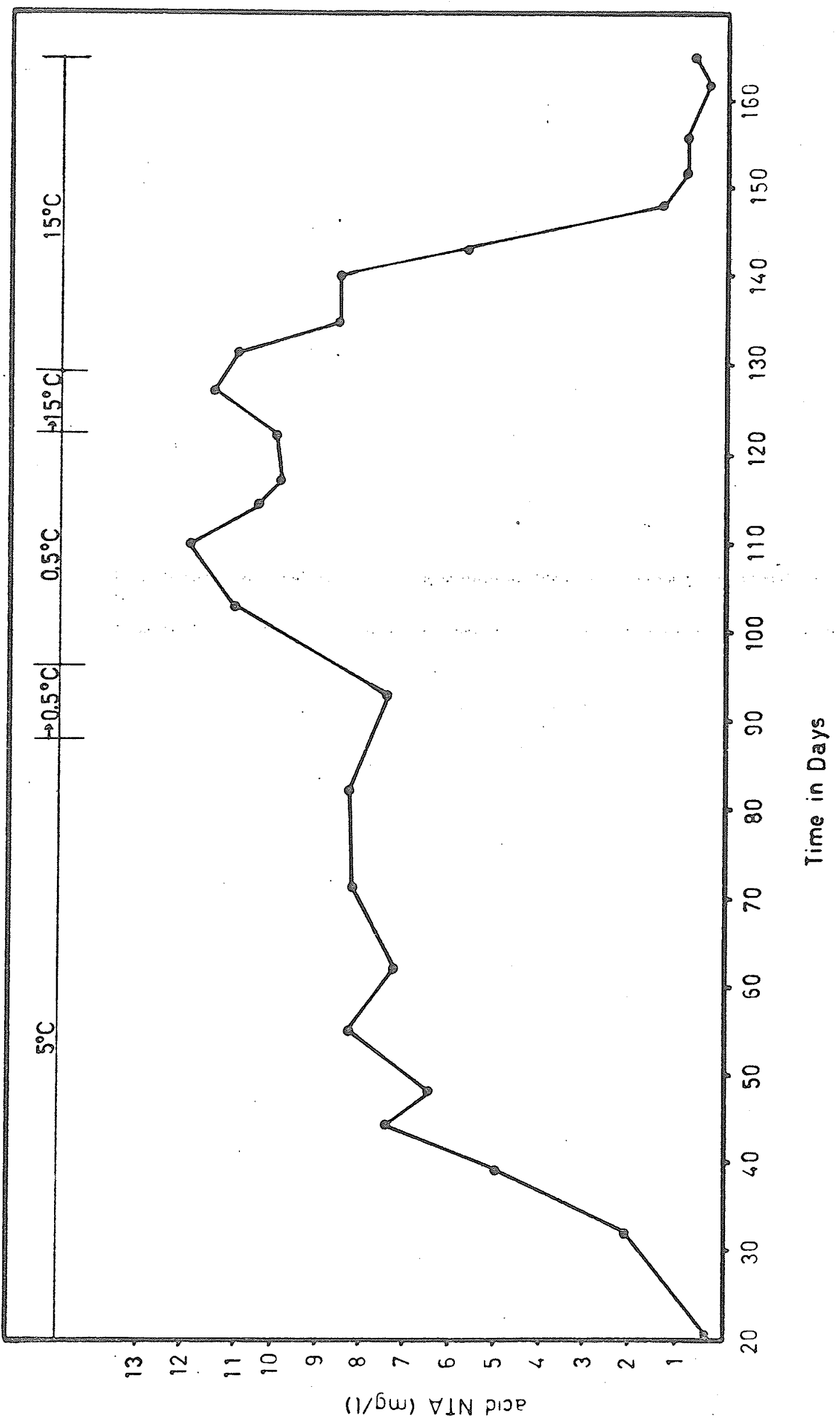


Fig. 9. Rate of NTA breakdown, by the model lagoon, as a function of temperature (see page 46). 


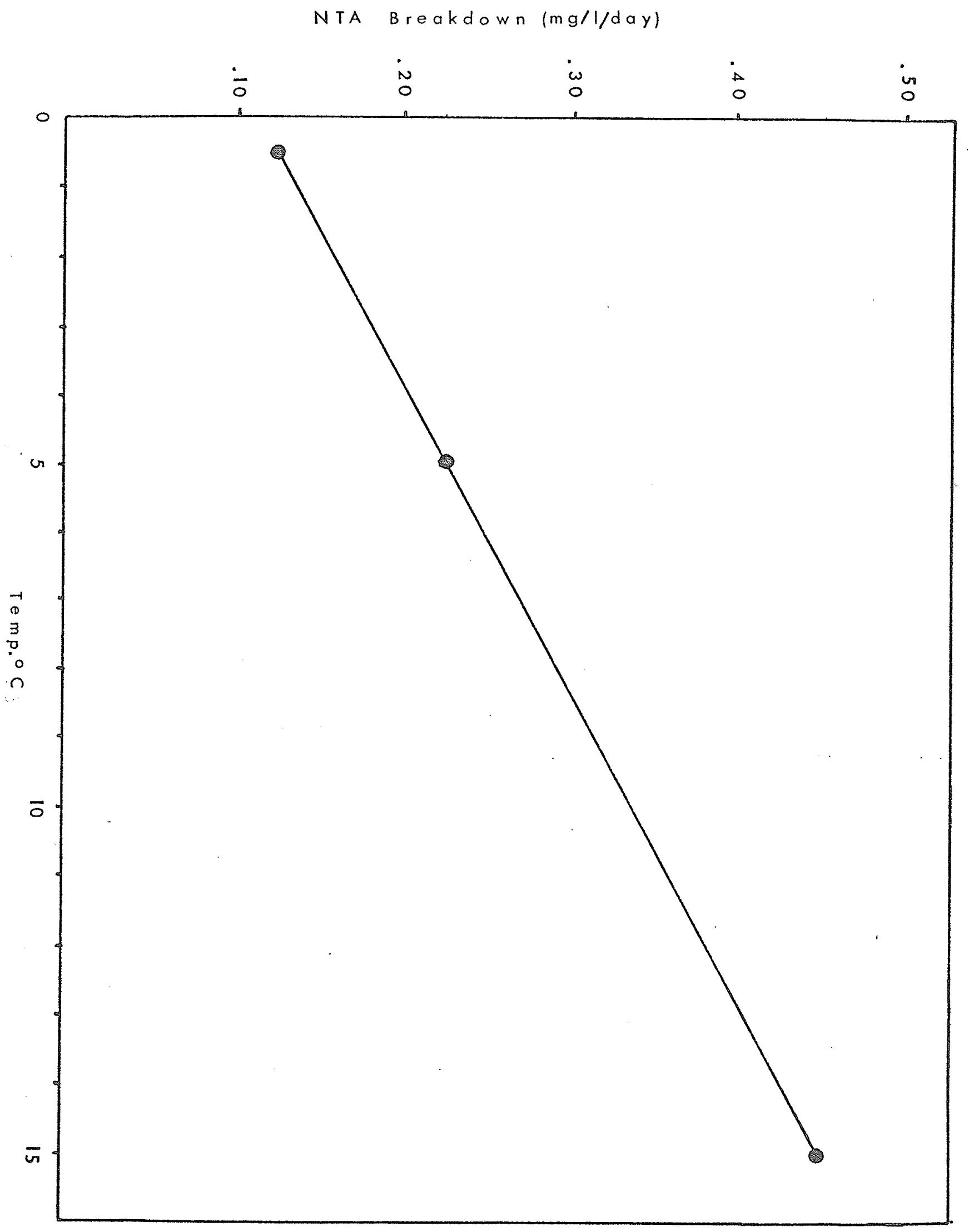


Fig. 10. Total suspended solids in the secondary effluent of the model lagoon, solid circles; suspended solids excluding Daphnia, crosses. Percent breakdown of NTA, open circles; percent suspended solids composed of Daphnia, broken line (see page 48 ). 


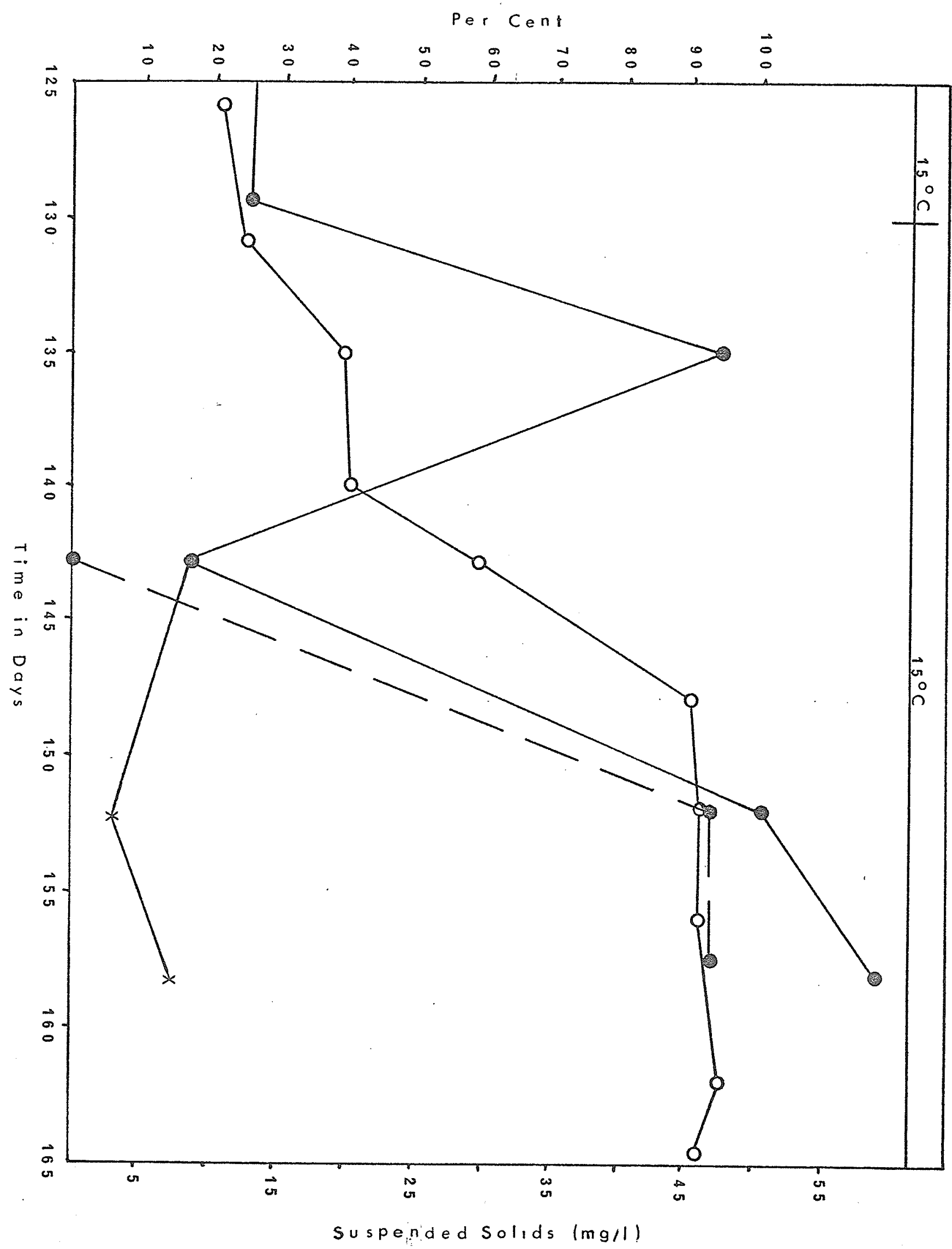


REFERENCES 


\section{REFERENCES}

1. Flannagan, J.F. 1971. Toxicity evaluation of trisodium nitrilotriacetate to selected aquatic invertebrates and amphibians. F.R.B. of Canada Tech. Report No.258.

2. McKinney, R.E. 1968. Overloaded oxidation ponds - two case studies. J. Water Pollution Control Federation. 40: 49-56.

3. Caldwell, D.H. 1946. Sewage oxidation ponds - performance, operation and design。 Sewage Works Jour。18:433-458.

4. Voege, F.A: and Stanley, D.R. 1963.' Industrial waste stabilization ponds in Canada. J. Water Pollution Control Federation: 35: 1416-1421。

5. Water and pollution control's 1970-71 directory. September 1970. 18-30. (Southam Business Publications Limited, Don Mills, Ontario, $90 \mathrm{pp}$.

6. Halvorson, $H_{0}$ Ishaque, $M_{0}$ and Lees, $H_{0}$ 1968. Microbiology of domestic wastes. I. Physiological activity of bacteria indigenous to lagoon operation as a function of seasonal change. Can. J. Microbiol. 14: 369-376.

7. Edmondson, W.T. 1970. Phosphorus, nitrogen, and algae in Lake Washington after diversion of sewage. Science. $169-690-691$. 
8. Vallentyne, J.R., Johnson, W.E. and Harris, A.J. 1970.

A visual demonstration of the beneficial effects of sewage treatment for phosphate removal on particulate matter production in waters of Lakes Erie and Ontario. J. Fish. Res. Bd. Canada. 27: 1493-1496.

9. Phosphates in detergents and the eutrophication of America's waters. 1970。 Twenty-Third Report by the Committee on Government Operations. p. 12.

10. International Joint Commission Canada and United States. 1970. Pollution of Lake Erie, Lake Ontario and the International Section of the St. Lawrence River。 p. 137 .

11. Pollard, R。 R。 1966. Amino acid chelating agents in detergent。 Soap and Chemical Specialities. 42: 58-62, 130-135.

12. Krumrei, W.C. Statement of Procter and Gamble Company on trisodium nitriloriactate to the Subcommittee on Air and Water Pollution of the Senate Committee on Public Works Appendix II. May 27, 1970. 
13. Phosphates may lose detergent markets. May 1, 1967. C. and En. 18-20.

14. Heintz, W. 1862. Annalen, 122: 257. Quoted in, Smith, R.I. 1959. The sequestration of metals, p. 71 (Chapman and Hall Limited, 256 pp.)。

15. Smith, RoI. 1959. The sequestration of metals, p. 71-72 (Chapman and Hall Limited, 256 pp.)。

16. Singer, J.J. Statement on NTA before the Natural Resources Subcommittee. December 15-16, 1969.

17. Provasoli, L., MeLaughlin, J.J.A. and Droop. M.R. 1957. The development of artificial media for marine algae. Arch. fur Mikrobiol. 25: 392-428.

18. Nixon, G.A. 1971. Toxicity evaluation of trisodium nitrilotriacetate. Toxicol. Appl. Pharmacol. 18: $398-406$.

19. Krumrei, W.C. Statement of Procter and Gamble Company on trisodium nitrilotriacetate to the subcommittee on Air and Water Pollution of the Senate Committee on Public Works, Appendix I. May 27, 1970. 
20. Michael, W.R. and Wakim, J.M. 1971. Metabolism of nitrilotriacetic acid (NTA). Toxicol. Appl. Pharmacol. 18: 407-416.

21. Scott, D.P. Personal communication.

22. Sprague, J.B. 1968. Promising anti-pollutant: chelating agent NTA protects fish from copper and zinc. Nature. 220: $1345-1346$.

23. Jancovic, $\mathbb{M}_{0}$ and Mann, $H_{0}$ 1969. Experiments on the acute toxic effect of nitrilotriacetate (NTA). Archiv fur Fischereiwissenschaft. 20: 178-182.

24. Swisher, R.D. and Mitchell, D.T. 1970. NTA and the environment, a review of the literature and work in progress. A report by the Inorganic Chemicals Division, Monsanto Company.

25. Christie, A.E. 1969. Trisodium nitrilotriacetate and algae.' Ont. Water Resources Comm., Div。 Res. Paper No. 2023.

26. Forsberg, C., Jinnerot, D. and Davidsson, L. 1967. The influence of synthetic detergents on the growth of algae. Vatten. 1: 1-16. 
27. Forsberg, C. and Wiberg, L. 1968. Om fosforutflockning i avloppsvatten, NTA och algtillvaxt. Vatten。 2: 143-148.

28. Forsberg, C. 1968. Effects of nitrilotriacetate (NTA) on ${ }^{14}$ Cassimilation and growth of algae. Vatten。 4:339-347.

29. Forsberg, Co and Lindqvist, Go 1967. Experimental studies on bacterial degradation of nitrilotriacetate, NTA. Vatten。 4: $265-277$.

30. Bouveng, $\mathrm{H}_{0} \mathrm{O}_{0}$, Davisson, $\mathrm{G}_{0}$ and Steinberg, E。 1968. NTA in sewage treatment, Vatten。 $4: 348-359$.

31. Swisher, R。D。, Crutchfield, $M_{0} M_{0}$ and Caldwell, D。W.1967. Biodegradation of nitrilotriacetate in activated sludge. Environ.Sci。Technol。1: 820-827.

32. Pfeil, $B_{0} H_{0}$ and Lee, G. F。 1968. Biodegradation of nitrilotriacetate in aerobic systems. Environ. Sci. Technol.2: $543-546$.

33. Shumate, K. S。, Thompson, J.E., Brookhart, J.D. and Dean, C. L。 1970. NTA removal by activated sludge - field study. J. Water Pollution Control Federation, 42: 631-640。

34. Thompson, J。E。 and Duthie, J.R. 1968. The biodegradability and treatability of NTA。 J。 Water Pollution Control Federation. 40:306-318. 
35. Bouveng, $H_{0} \mathrm{O}_{0}$, Solyom, $P_{0}$ and Werner, J. 1970. NTA in sewage treatment. Part 2。 Degradation of NTA in a trickling filter and oxidation pond. Vatten。 4: 389-402.

36. Hamilton, R,D. Personal communication。

37. Metropolitan Corporation of Greater Winnipeg, Waterworks and Waste Disposal Division. 1970。 Evaluation of Aerated Lagoons in Metropolitan Winnipeg, 71 pp。

38. Thabaraj, G. J. Gaudy, A. F。 1969. Effect of dissolved oxygen on the metabolic response of completely mixed activated sludge. JoWater Pollution Control Federation. 41: R322-R335.

39. Standard methods for the examination of water and waste water. 12th ed. American Public Health Association, Inc. New York, N.Y。

40. Siddiqi, R。 $H_{0}$, Speece, R. E。, Engelbrecht, R。S。 and Schmidt, J.W. 1967. Elimination of nitrification in the BOD determination with $0.10 \mathrm{M}$ ammonia nitrogen. J. Water Pollution Control Federation。39:579-589.

41. Suzuki, I. Personal communication. 
42. Morris, and Riley。 1963. Anal. Chim.Acta. 29:272. Quoted in, Strickland, J. D. H. and Parsons, T.R.1968. A practical handbook of seawater analysis, $p_{0} 71$ (F。R, B。 of Canada, 311 pp。).

43. Flett, R。J。 Personal communication.

44. Murray, D。 and Poveledo, D。 In press. The determination of nitrilotriacetic acid in inland waters by gas chromatography of the trimethyl ester. J.Fish.Res。Bd. Canada.

45. Ishaque, $M_{0}$ 1968。 $\mathrm{Ph}$. $\mathrm{D}$ 。 thesis, University of Manitoba.

46. Government of Canada. 1970. Phosphorus concentration control regulations。 Order - In - Council P.C。1970-1341。

47. Carrol, W. Personal communication.

48. Richman, S. 1958. The transformation of energy by Daphnia pulex. Ecol. Monogr。28:273-291。

49. Prescott, GoW。 1968. The algae: a review, po 339 (Houghton Mifflin Company, Boston, 436 pp。)。

50. Meterological Branch, Department of Transport, Canada. 1968. Climatic normals, volume I temperature.

51. Johannes, R。E。1968. Nutrient regeneration in lakes and oceans. Advances in Microbiology of the Sea, 1:203-213. 
52. Javornicky, P. and Prokesova, V. 1963. The influence of protozoa and bacteria upon the oxidation of organic substances in water. Int. Revue ges. Hydrobioll 48: 335-350。

53. Straskrabova, V. and Legner, M. 1969. The quantitative relation of bacteria and ciliates to water pollution. in Advances in water pollution research proceedings of the 4th international conference held in Prague 1969, p. 57-67 (Pergamon Press, Oxford and New York)。 